\title{
The end of Midcontinent Rift magmatism and the paleogeography of Laurentia
}

\author{
Luke M. Fairchild', Nicholas L. Swanson-Hysell', Jahandar Ramezani², Courtney J. Sprain'1, and Samuel A. Bowring ${ }^{2}$ \\ 'DEPARTMENT OF EARTH AND PLANETARY SCIENCE, UNIVERSITY OF CALIFORNIA, BERKELEY, CALIFORNIA 94720, USA \\ 2DEPARTMENT OF EARTH, ATMOSPHERIC AND PLANETARY SCIENCES, MASSACHUSETTS INSTITUTE OF TECHNOLOGY, CAMBRIDGE, MASSACHUSETTS 02139, USA
}

\section{ABSTRACT}

Paleomagnetism of the North American Midcontinent Rift provides a robust paleogeographic record of Laurentia (cratonic North America) from ca. 1110 to $1070 \mathrm{Ma}$, revealing rapid equatorward motion of the continent throughout rift magmatism. Existing age and paleomagnetic constraints on the youngest rift volcanic and sedimentary rocks have been interpreted to record a slowdown of this motion as rifting waned. We present new paleomagnetic and geochronologic data from the ca. 1090-1083 Ma "late-stage" rift volcanic rocks exposed as the Lake Shore Traps (Michigan), the Schroeder-Lutsen basalts (Minnesota), and the Michipicoten Island Formation (Ontario). The paleomagnetic data allow for the development of paleomagnetic poles for the Schroeder-Lutsen basalts $\left(187.8^{\circ} \mathrm{E}, 27.1^{\circ} \mathrm{N} ; A_{95}=3.0^{\circ}, N=50\right)$ and the Michipicoten Island Formation $\left(174.7^{\circ} \mathrm{E}, 17.0^{\circ} \mathrm{N} ; A_{95}=4.4^{\circ}, N=23\right)$. Temporal constraints on late-stage paleomagnetic poles are provided by high-precision, ${ }^{206} \mathrm{~Pb}^{238} \mathrm{U}$ zircon dates from a Lake Shore Traps andesite (1085.57 $\pm 0.25 \mathrm{Ma} ; 2 \sigma$ internal errors), a Michipicoten Island Formation tuff (1084.35 $\pm 0.20 \mathrm{Ma}$ ) and rhyolite $(1083.52 \pm 0.23 \mathrm{Ma})$, and a Silver Bay aplitic dike from the Beaver Bay Complex $(1091.61 \pm 0.14 \mathrm{Ma})$, which is overlain by the Schroeder-Lutsen basalt flows. These Michipicoten Island Formation dates are the youngest yet obtained from Midcontinent Rift volcanic rocks and indicate that rift magmatism was active for at least 25 m.y. The addition of these late-stage paleomagnetic poles to the Laurentian apparent polar wander path suggests that rapid motion of Laurentia continued throughout the entirety of rift volcanism.

\section{INTRODUCTION}

The 1.1 Ga Midcontinent Rift of North America is a failed intracontinental rift that was active for $\sim 25 \mathrm{~m}$.y. Paleomagnetic and geochronologic data from Midcontinent Rift volcanic rocks have yielded a well-resolved apparent polar wander path (APWP) known as the Keweenawan Track, which records dramatic paleogeographic change throughout the life span of the rift. This APWP is buttressed by over half a century of paleomagnetic study in the Midcontinent Rift (Halls and Pesonen, 1982, and references therein) and is foundational to work focused on reconstructing Proterozoic paleogeography (e.g., Li et al., 2008; Evans, 2009). The pioneering work of Rob Van der Voo and his group at the University of Michigan led to the development of poles from Keweenawan sedimentary rocks that extend the Keweenawan Track into the interval of sedimentation that followed rift magmatism (Henry et al., 1977; McCabe and Van der Voo, 1983). This work produced poles that remain in use for paleogeographic reconstructions to this day (e.g., Li et al., 2008). Subsequently, Rob Van der Voo and Ben van der Pluijm worked collaboratively and advised Jim Hnat on a project that developed many more data from the Portage Lake Volcanics (Hnat et al., 2006), which also serve as important constraints for the Keweenawan Track.

The magmatic products of the Midcontinent Rift are exceptional in that they are both voluminous and largely confined to an intracratonic rift (Green, 1983; Stein et al., 2015). The total volcanic output is dominated

Luke Fairchild (D) http://orcid.org/0000-0003-2512-7852 by basaltic lavas and has been estimated at $\sim 1.5 \times 10^{6} \mathrm{~km}^{3}$ (Hutchinson et al., 1990; Cannon, 1992), characteristic of large igneous province magmatism fed by a mantle plume. However, large igneous provinces associated with the arrival of upwelling mantle plumes often result in short ( 1 m.y.) pulses of intense and voluminous volcanism (e.g., Blackburn et al., 2013; Burgess et al., 2015; Renne et al., 2015). In contrast, magmatism in the Midcontinent Rift was prolonged over tens of millions of years. Current constraints have estimated volcanism in the Midcontinent Rift to have initiated ca. $1109 \mathrm{Ma}$ (Davis and Sutcliffe, 1985) and continued to ca. $1087 \mathrm{Ma}$ (Davis and Paces, 1990). Given the longevity and volcanic output of the Midcontinent Rift, the reason why the rift ultimately failed to dismember the ancient North American craton, Laurentia, continues to be a topic of active interest.

Midcontinent Rift magmatism has been subdivided into four intervals, termed the early (ca. 1109-1105 Ma), latent (ca. 1105-1100 Ma), main (ca. 1100-1094 Ma), and late (younger than ca. $1094 \mathrm{Ma}$ ) stages (Fig. 1; Miller and Vervoort, 1996; Davis and Green, 1997; Vervoort et al., 2007). These temporal stages are distinguished by the nature of their magmatic activity and relative volcanic volume, and they have been argued to correlate with different intervals of the rift's geodynamic and structural evolution (Miller and Nicholson, 2013). The timing at which late-stage volcanism ended is of interest not only for constraining the overall duration of volcanism in the rift, but also for models of rift progression, cessation, and structural inversion, which may hinge on temporal correlation with far-field tectonic events (Cannon and Hinze, 1992; Cannon, 1994; Stein et al., 2014). The ages of late-stage volcanic rocks 


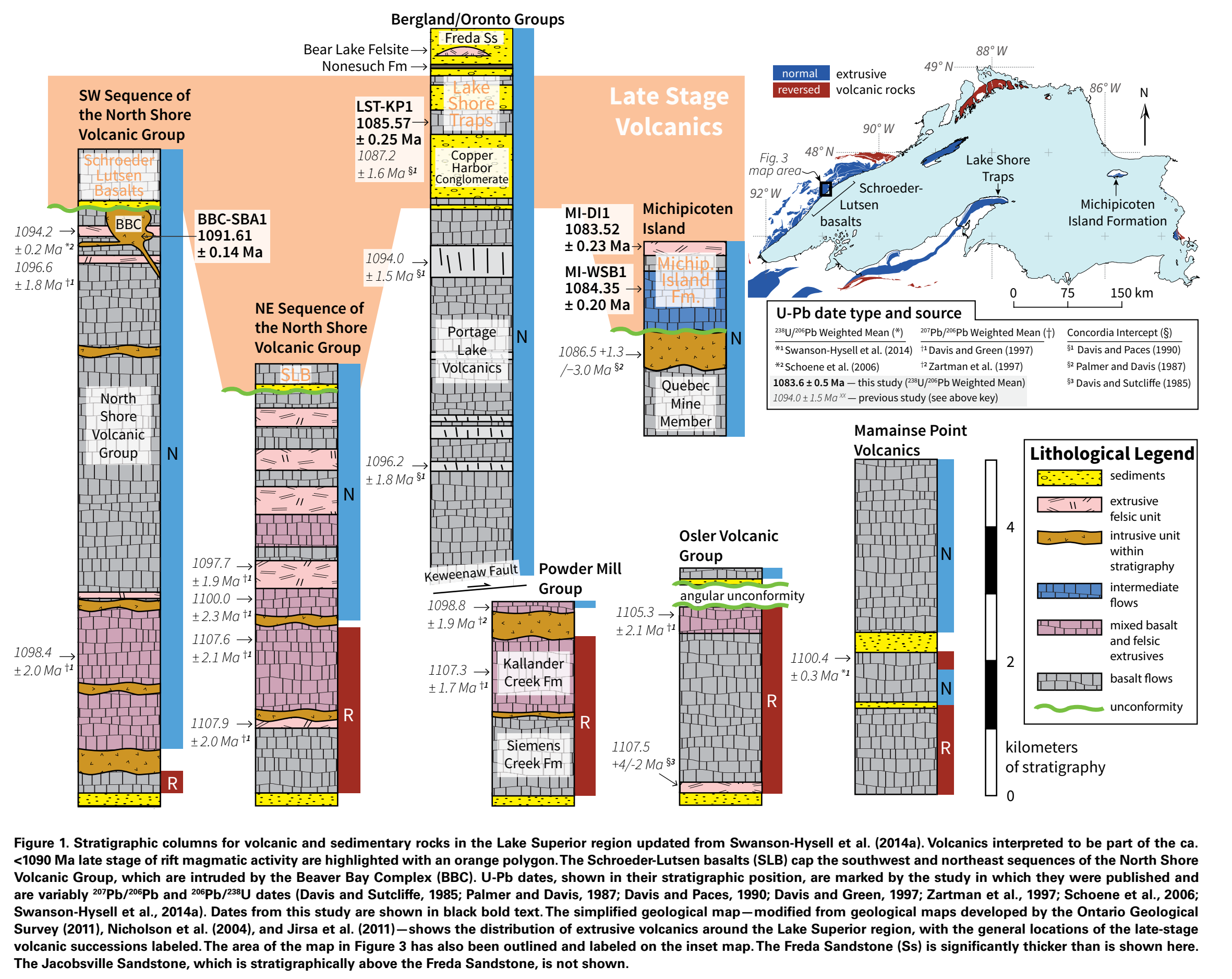

Figure 1. Stratigraphic columns for volcanic and sedimentary rocks in the Lake Superior region updated from Swanson-Hysell et al. (2014a). Volcanics interpreted to be part of the ca. $<1090 \mathrm{Ma}$ late stage of rift magmatic activity are highlighted with an orange polygon. The Schroeder-Lutsen basalts (SLB) cap the southwest and northeast sequences of the North Shore Volcanic Group, which are intruded by the Beaver Bay Complex (BBC). U-Pb dates, shown in their stratigraphic position are marked by the study in which they were published and are variably ${ }^{207} \mathrm{~Pb} / 206 \mathrm{~Pb}$ and ${ }^{206 \mathrm{~Pb} / 238 \mathrm{U}}$ dates (Davis and Sutcliffe, 1985; Palmer and Davis, 1987; Davis and Paces, 1990; Davis and Green, 1997; Zartman et al., 1997; Schoene et al., 2006; 
The end of Midcontinent Rift magmatism and the paleogeography of Laurentia $\mid$ THEMED ISSUE

also constrain the young end of the Keweenawan APWP before the path transitions into poles from sedimentary rocks, for which it is more difficult to develop firm geochronological constraints. Current compilations of the Keweenawan Track show a significant directional difference between the late-stage pole of the Lake Shore Traps (Diehl and Haig, 1994) and the poles of younger sedimentary rocks (Henry et al., 1977)—even from sedimentary rocks of the Nonesuch and Freda Formations, which were likely deposited soon after or even during eruption of the youngest rift volcanic rocks. Improved paleomagnetic and geochronologic constraints on additional late-stage Midcontinent Rift volcanic rocks could bridge this gap between the cessation of rift volcanism and the deposition of these sediments.

In this contribution, we seek to strengthen constraints on Laurentia's position during the later stages of Midcontinent Rift magmatism by integrating new paleomagnetic data with high-precision $\mathrm{U}-\mathrm{Pb}$ geochronology (chemical abrasion-isotope dilution-thermal ionization mass spectrometry [CA-ID-TIMS] method) from what have been interpreted as some of the youngest volcanic rocks of the rift. These include the Schroeder-Lutsen basalt flows and the Michipicoten Island Formation in the western and eastern regions of the Lake Superior Basin, respectively. In addition, we present a new date for another late-stage volcanic sequence, the Lake Shore Traps, located on the Keweenaw Peninsula of Michigan. Taken altogether, the new data allow us to address when Midcontinent Rift volcanism ceased and where Laurentia was located at that time. These data also add greater resolution to the Keweenawan Track of Laurentia's APWP, allowing us to better assess the rate of plate motion recorded by rift volcanic rocks.

\section{METHODS}

\section{Paleomagnetism Methods}

Cores from the studied lava flows were collected using a Pomeroy gas-powered drill and a Pomeroy orienting device. Sun compass data were used for sample orientations when possible, although cloud cover occasionally necessitated the use of magnetic compass orientations. Thermal demagnetization and measurements of magnetic remanence were conducted at the UC Berkeley Paleomagnetism Laboratory. Measurements were made using a $2 \mathrm{G}$ Enterprises DC-SQUID superconducting rock magnetometer equipped with an automated pick-and-place sample changer system (Kirschvink et al., 2008). The magnetometer is housed in a magnetostatic shield with magnetic fields $<500 \mathrm{nT}$. A quartz glass sample rod brings the samples into the measurement region and is typically measured at $\sim 5 \times 10^{-12} \mathrm{Am}^{2}$ or below. After measurement of the natural remanent magnetization (NRM), and prior to thermal demagnetization steps, the samples underwent liquid nitrogen immersion, during which they equilibrated at $77 \mathrm{~K}$ and then warmed back to room temperature, all in a low-magnetic-field environment $(<10 \mathrm{nT})$. This low-temperature step was implemented with the goal of preferentially removing remanence associated with multidomain magnetite. Many such multidomain grains undergo low-temperature demagnetization when cycled through the isotropic point $(\sim 130 \mathrm{~K})$ and the Verwey transition ( 120 K; Verwey, 1939; Feinberg et al., 2015). Subsequently, the samples were progressively step-heated and thermally demagnetized in an ASC thermal specimen demagnetizer (residual fields $<10 \mathrm{nT}$ ). Following acquisition of the data, principal component analysis (Kirschvink, 1980) was conducted using the PmagPy software package (https://github.com/PmagPy; Tauxe et al., 2016). All measurement level data as well as interpreted specimen directions are available within the MagIC database (https://earthref.org/MagIC /doi/10.1130/L580.1).

\section{Geochronology Methods}

Age constraints on the paleomagnetic poles were developed through $\mathrm{U}-\mathrm{Pb}$ geochronology using CA-ID-TIMS on zircon grains from the felsic to intermediate volcanic, shallow-intrusive, and pyroclastic lithologies of the studied units. Zircon grains were isolated from bulk rock by standard crushing, pulverizing, magnetic, and high-density liquid separation techniques. All U-Pb analyses were made on carefully selected, single zircon crystals that were pretreated by a chemical-abrasion technique modified after Mattinson (2005) and analyzed following the procedures described in Ramezani et al. (2011). Chemical abrasion involved leaching in $29 \mathrm{M}$ $\mathrm{HF}$ at $210^{\circ} \mathrm{C}$ for 11.5 to $12 \mathrm{~h}$. This intensive leach schedule often caused extensive disintegration (or near-complete dissolution) of zircons, but it was deemed necessary in order to fully mitigate the effects of $\mathrm{Pb}$ loss due to accumulated radiation damage in ca. $1.1 \mathrm{Ga}$ zircons. Pretreated zircons were spiked with the EARTHTIME ET535 mixed ${ }^{205} \mathrm{~Pb}^{233} \mathrm{U}-{ }^{235} \mathrm{U}$ tracer and, when appropriate, ET2535 tracer solution containing additional ${ }^{202} \mathrm{~Pb}$ (Condon et al., 2015; McLean et al., 2015) prior to complete dissolution and analysis. Measurements of $\mathrm{Pb}$ and $\mathrm{U}$ isotopic ratios were made on a VG Sector 54 or Isotopx X62 multicollector TIMS equipped with Daly photomultiplier ion-counting systems at the Massachusetts Institute of Technology (MIT) Isotope Laboratory. Complete $\mathrm{U}$ and $\mathrm{Pb}$ isotopic data are presented in Table S1 in the GSA Data Repository Item. ${ }^{1}$

Data reduction, $\mathrm{U}-\mathrm{Pb}$ date calculation, and error propagation were carried out using the Tripoli and ET_Redux algorithms and computer applications (Bowring et al., 2011; McLean et al., 2011). Analyses were corrected for initial ${ }^{230} \mathrm{Th}$ disequilibrium in magma using an estimated felsic magma Th/U ratio of $2.8 \pm 1(2 \sigma)$. Sample dates representing zircon crystallization ages were calculated based on the weighted mean ${ }^{206} \mathrm{~Pb} /{ }^{238} \mathrm{U}$ date of the analyzed zircons from each sample, after excluding older analyses interpreted as xenocrystic. There was only one case (sample MI-WSB1) in which younger analyses evidently affected by persistent $\mathrm{Pb}$ loss were excluded. Weighted mean date uncertainties are reported in the $\pm X / Y / Z$ format, where $X$ is the $2 \sigma$ analytical error exclusive of all external sources of uncertainty, $Y$ includes $X$ and the additional tracer calibration error, and $Z$ incorporates the $U$ decay constant uncertainties of Jaffey et al. (1971). Calculated weighted mean dates and their uncertainties are given in Table 1 and are illustrated in the age distribution plot of Figure 2. The uncertainty from tracer calibration $(Y)$ must be taken into account when comparisons are made between $\mathrm{U}-\mathrm{Pb}$ dates from different techniques or from different ID-TIMS laboratories using different tracers. For comparison between dates from different chronometers (e.g., U-Pb vs. $\left.{ }^{40} \mathrm{Ar} /{ }^{39} \mathrm{Ar}\right)$, the total uncertainty $(Z)$ must be considered.

Before the advent of the CA-TIMS pretreatment technique, zircons for $\mathrm{U}-\mathrm{Pb}$ geochronology were customarily subjected to a mechanical (air) abrasion procedure after Krogh (1982). Though highly beneficial, the latter technique was demonstrably less efficient in eliminating $\mathrm{Pb}$ loss, which would result in anomalously young (and discordant) ${ }^{206} \mathrm{~Pb} /{ }^{238} \mathrm{U}$ and ${ }^{207} \mathrm{~Pb} /{ }^{235} \mathrm{U}$ dates. The majority of previously published $\mathrm{U}-\mathrm{Pb}$ ages from Midcontinent Rift magmatic rocks were thus calculated based on ${ }^{207} \mathrm{~Pb} /{ }^{206} \mathrm{~Pb}$ or concordia intercept dates from discordant zircon analyses, thereby limiting precision (e.g., Palmer and Davis, 1987; Davis and Paces, 1990; Davis and Green, 1997). It has been shown that even for statistically coherent sets of U-Pb data (i.e., no detectable scatter due to U-Pb open-system behavior), the ${ }^{207} \mathrm{~Pb} /{ }^{206} \mathrm{~Pb}$ dates turn out to be systematically older than the corresponding ${ }^{206} \mathrm{~Pb} /{ }^{338} \mathrm{U}$ dates, once internal precision approaches the per mil level

'GSA Data Repository Item 2017043, details of paleomagnetic and paleogeographic data analysis and geochronology data, is available at www.geosociety .org/datarepository/2017, or on request from editing@geosociety.org. 
TABLE 1. SUMMARY OF CALCULATED U-Pb AGES AND THEIR UNCERTAINTIES

\begin{tabular}{|c|c|c|c|c|c|c|c|c|c|c|c|}
\hline \multirow[b]{2}{*}{ Sample } & \multirow[b]{2}{*}{ Rock type } & \multirow[b]{2}{*}{ Unit } & \multirow[b]{2}{*}{ Latitude $\left({ }^{\circ} \mathrm{N}\right)$} & \multirow{2}{*}{$\begin{array}{c}\text { Longitude } \\
\quad\left({ }^{\circ} \mathrm{W}\right)\end{array}$} & \multirow{2}{*}{$\frac{{ }^{206} \mathrm{~Pb}}{{ }^{238} \mathrm{U}}$} & \multirow[b]{2}{*}{ age } & \multicolumn{3}{|c|}{ Uncertainty $(2 \sigma)$} & \multirow[b]{2}{*}{ MSWD } & \multirow[b]{2}{*}{$n$} \\
\hline & & & & & & & $x$ & $Y$ & $Z$ & & \\
\hline BBC-SBA1 & Aplite & Silver Bay intrusion & 47.3143 & 91.2281 & 109 & & 0.14 & 0.30 & 1.2 & 1.0 & 6 \\
\hline LST-KP1 & Andesite & Lake Shore Traps & 47.4305 & 87.7143 & 108 & & 0.25 & 0.50 & 1.3 & 1.5 & 5 \\
\hline MI-WSB1 & Lithic tuff & West Sandy Bay Tuff & 47.7117 & 85.8871 & 108 & & 0.20 & 0.34 & 1.2 & 0.88 & 6 \\
\hline MI-DI1 & Rhyolite & Davieaux Island Rhyolite & 47.6947 & 85.8056 & 108 & & 0.23 & 0.35 & 1.2 & 0.86 & 5 \\
\hline
\end{tabular}

Note: Latitude/Longitude is relative to the World Geodetic System 1984 (WGS84) datum. $X$-internal (analytical) uncertainty in the absence of all external or systematic errors; $Y$-incorporates the $U-P b$ tracer calibration error; $Z$-includes $X$ and $Y$, as well as the uranium decay constant errors; MSWD-mean square of weighted deviates; $n$-number of analyses included in the calculated weighted mean date.

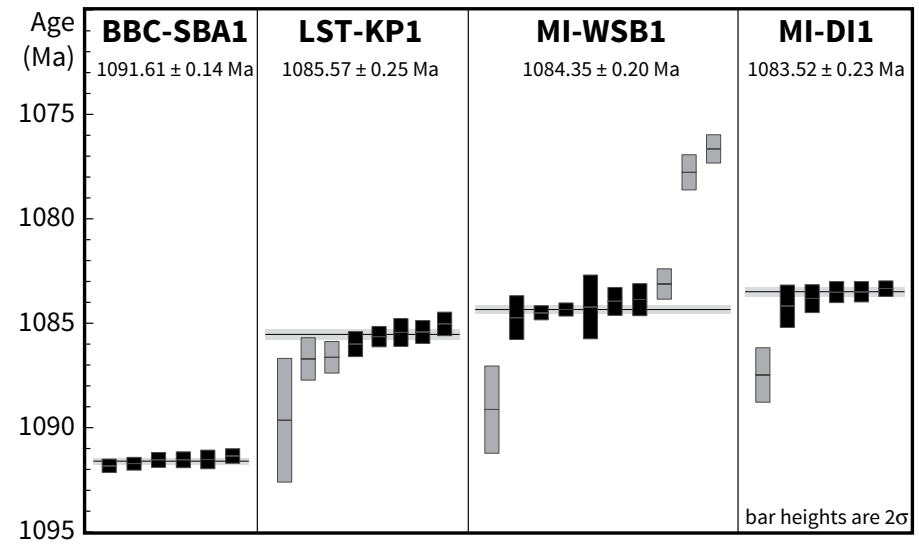

Figure 2. U-Pb date distribution plots of the analyzed samples from the Midcontinent Rift magmatic rocks. Vertical bars represent $2 \sigma$ analytical uncertainty of individual zircon analyses; solid bars are data used in age calculation. Horizontal lines and shaded bands signify weighted mean ${ }^{206} \mathrm{~Pb} /{ }^{238} \mathrm{U}$ dates and their $2 \sigma$ uncertainties, respectively. See Table S1 in Data Repository Item for complete U-Pb data, as well as text and Table 1 for details of geochronology.

(Schoene et al., 2006). This behavior has been attributed to possible inaccuracies in the decay constants of U (Schoene et al., 2006; Mattinson, 2010). Therefore, the high-precision weighted mean ${ }^{206} \mathrm{~Pb} /{ }^{238} \mathrm{U}$ dates reported here are expected to be systematically younger-and more accurate - than the previously published ${ }^{207} \mathrm{~Pb} /{ }^{206} \mathrm{~Pb}$ - and concordia intercept-based geochronology from the same rocks.

\section{PALEOMAGNETISM AND GEOCHRONOLOGY OF LATE-STAGE MIDCONTINENT RIFT VOLCANIC ROCKS}

\section{Lake Shore Traps}

\section{Geological Setting and Geochronology}

The Lake Shore Traps are a sequence of basaltic to andesitic lava flows exposed along the eastern tip and the north side of the Keweenaw Peninsula (Fig. 1; Lane, 1911; Cannon and Nicholson, 2001). The lava flows are intercalated with the Copper Harbor Conglomerate and are underlain by the thick flood basalt succession of the Portage Lake Volcanics (Fig. 1). Existing age constraints on the Lake Shore Traps come from a weighted mean ${ }^{207} \mathrm{~Pb} /{ }^{206} \mathrm{~Pb}$ ID-TIMS date of 1087.2 \pm 1.6 Ma obtained by Davis and Paces (1990) based on multigrain zircon fractions from a feldspar-phyric andesite flow within the upper lavas of the middle Lake Shore Traps. Our sample from the same feldspar-phyric andesite flow (sample LST-KP1; Fig. 2; Table 1) yielded a weighted mean ${ }^{206} \mathrm{~Pb} /{ }^{238} \mathrm{U}$ date of $1085.57 \pm 0.25 / 0.50 / 1.3$ Ma based on five single-zircon analyses, with a mean square of weighted deviates (MSWD) of 1.3, after excluding resolvably older analyses interpreted as xenocrystic. We consider this $1085.57 \pm 0.25$ Ma date as the best available constraint on the age of the Lake Shore Traps paleomagnetic pole.

\section{Paleomagnetic Data and Pole}

The youngest pole commonly utilized from Midcontinent Rift volcanic rocks is that of the Lake Shore Traps (Diehl and Haig, 1994; Kulakov et al., 2013). Paleomagnetic data from 30 Lake Shore Traps flows were published by Diehl and Haig (1994), and data from an additional 21 flows were published by Kulakov et al. (2013). Kulakov et al. (2013) added more data from the sequence of flows on the eastern tip of the peninsula, and from Silver Island and the nearby mainland. The virtual geomagnetic poles (VGPs) from the Lake Shore Traps are distinctly non-Fisherian in distribution and fall into three clusters (Fig. 6). Diehl and Haig (1994) discussed this pattern of the data wherein the three distinct clusters comprise: (1) the lower lava flows of the middle Lake Shore Traps; (2) the upper lava flows of the middle Lake Shore Traps; and (3) the flows of the outer Lake Shore Traps. The interpretation of Diehl and Haig (1994, p. 379) was that each of these clusters could be considered to be underaveraging secular variation and that each package considered by itself would "lead to an erroneous positioning of the pole." Diehl and Haig (1994) considered the mean pole to be a good overall fit to the data, given the near-equal number of VGPs in each grouping. Paleomagnetic data from additional Lake Shore Traps lava flows reported by Kulakov et al. (2013) dominantly added data from the eastern cluster of middle Lake Shore Traps VGPs. The overall effect of this addition is to weight the easterly population of VGPs and shift the overall mean pole to the east, as can be seen in Figure 6.

The non-Fisherian distribution of the data can be quantified using a quantile-quantile (Q-Q) plot and the test statistic approach of Fisher et al. (1987), which assess the goodness-of-fit of the Fisher (1953) model to directional data. The Fisher distribution takes VGP longitude to be uniformly distributed about a mean and VGP colatitude to be exponentially distributed about a mean (Fisher et al., 1987). Applying this test to the Lake Shore Traps VGPs reveals that they are inconsistent with a Fisher distribution (see Data Repository Item for details). Despite the non-Fisherian distribution, the mean pole still likely provides a good approximation of geographic north at the time of eruption and therefore remains an important constraint on the Laurentian APWP. Nevertheless, the irregular distribution of the VGPs provides additional motivation to develop data from other late rift successions to bolster the implied paleogeographic position of Laurentia during the late stage of Midcontinent Rift volcanism.

\section{Schroeder-Lutsen Basalts}

\section{Geological Setting and Geochronology}

The Schroeder-Lutsen basalts are a sequence of subophitic to ophitic olivine tholeiite basalts that stratigraphically overlie the lavas of the North Shore Volcanic Group (Fig. 1; Green et al., 2011). On the south end of their 
exposure, the Schroeder-Lutsen basalts are mapped as being in angular unconformity with the North Shore Volcanic Group, with deposition of the polymictic Little Marais conglomerate occurring above the unconformity in isolated regions (Miller and Chandler, 1997; Miller et al., 2006; Green et al., 2011). Below this unconformity, the generally simple structure of the upper southwest sequence of the North Shore Volcanic Group is strongly disturbed by the hypabyssal intrusions of the Beaver Bay Complex (Miller and Chandler, 1997; Miller and Green, 2002), whereas the Schroeder-Lutsen basalts remain undisturbed and were not penetrated by the intrusions (Fig. 3; Green et al., 2011). Therefore, dates from the Beaver Bay Complex can be considered maximum age constraints on the Schroeder-Lutsen basalts.

The hypabyssal intrusions that comprise the Beaver Bay Complex are interpreted to have been emplaced in multiple phases. Existing age constraints for the Beaver Bay Complex include weighted mean ${ }^{207} \mathrm{~Pb} /{ }^{206} \mathrm{~Pb}$ ID-TIMS zircon dates by Paces and Miller (1993) and come from the Sonju Lake intrusion $(1096.1 \pm 0.8 \mathrm{Ma})$ and a Silver Bay intrusion $(1095.8 \pm 1.2$ Ma). Mapping of the Beaver Bay Complex has led to the interpretation that the youngest intrusions in the southern portion of the complex are the Silver Bay intrusions (Miller and Chandler, 1997). These intrusions are composite bodies that were emplaced into the uppermost North Shore Volcanic Group and the older Beaver River diabase of the Beaver Bay Complex. Our geochronologic sample BBC-SBA1 (Table 1) was collected from a comagmatic aplite dike within the granophyre zone of an $2-\mathrm{km}$ diameter intrusion that is part of the Silver Bay intrusions (the same Silver Bay intrusive body from which the date was obtained by Paces and Miller, 1993). The granophyre zone of this intrusive body was sampled because it likely represents the youngest phase within one of the youngest Beaver Bay Complex intrusions. The intrusion occurs just west of Palisade Head, with map relationships showing it to crosscut both the Beaver River diabase and the North Shore Volcanic Group at a stratigraphic level near the Palisade Rhyolite (Fig. 1; Miller et al., 1989). All six analyzed zircons from the aplite dike form a statistically coherent cluster (Fig. 2) with a weighted mean ${ }^{206} \mathrm{~Pb} /{ }^{238} \mathrm{U}$ date of $1091.61 \pm 0.14 / 0.30 / 1.2 \mathrm{Ma}(\mathrm{MSWD}=$ 1.0; Table 1). This date is younger, as expected, than the previously reported ${ }^{206} \mathrm{~Pb} /{ }^{238} \mathrm{U}$ date of $1094.2 \pm 0.2 / 0.4 / 1.5 \mathrm{Ma}$ from the Palisade Rhyolite of the North Shore Volcanic Group (Schoene et al., 2006), based on a combination of air-abraded and CA-TIMS single-zircon analyses. Given that the Schroeder-Lutsen basalts are dominantly olivine tholeiites, there has yet to be a successful attempt to isolate suitable phases for $\mathrm{U}-\mathrm{Pb}$ geochronology from the succession. Therefore, our $1091.61 \pm 0.14$ Ma date currently serves as the best maximum age constraint for the Schroeder-Lutsen basalts.

\section{New Stratigraphic and Paleomagnetic Data}

Previous studies that have developed paleomagnetic data from flows of the Schroeder-Lutsen basalts have grouped those data with data from

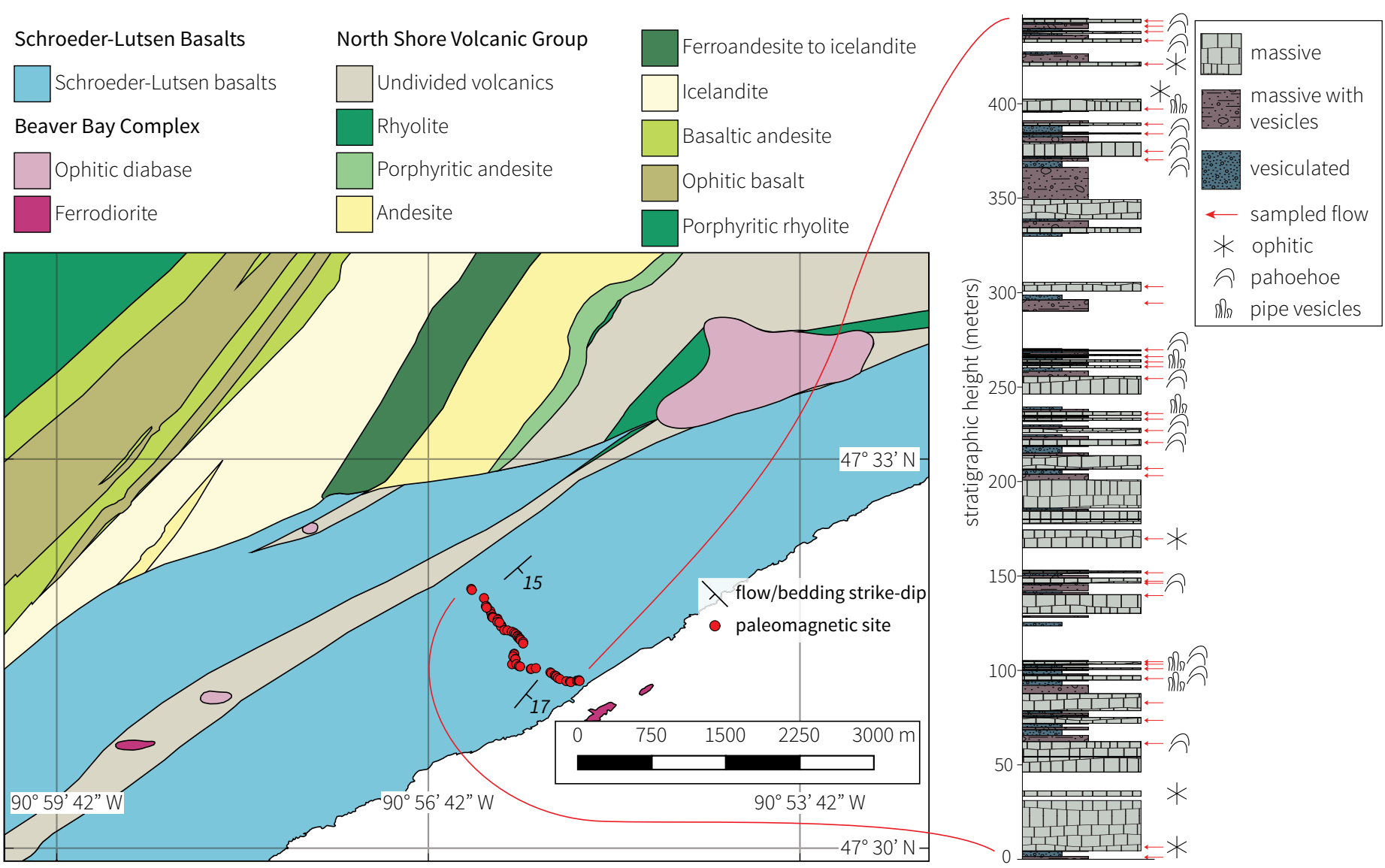

Figure 3. Geologic map and volcanostratigraphic column of the Schroeder-Lutsen basalts measured along the Two Island River. The bedrock geology (adapted from Boerboom and Green, 2006) includes units of the North Shore Volcanic Group, the Beaver Bay Complex, and the Schroeder-Lutsen basalts. Beaver Bay Complex intrusions are present within the North Shore Volcanic Group but not within the Schroeder-Lutsen sequence. Paleomagnetic sites are shown as red dots on the geological map and as red arrows on the volcanostratigraphic column. For regional context of this map, see inset map in Figure 1. 
underlying flows of the North Shore Volcanic Group when calculating means (e.g., Books, 1972; Halls and Pesonen, 1982; Tauxe and Kodama, 2009). Given the evidence for angular unconformity between the North Shore Volcanic Group and the Schroeder-Lutsen basalts, paleomagnetic data from the successions should be considered independently. The data developed by Tauxe and Kodama (2009) included data from 10 sites (each individual lava flows) within the Schroeder-Lutsen basalts. These VGPs are of high quality and suggest that the Schroeder-Lutsen basalts were emplaced at lower latitude than the North Shore Volcanic Group (see Data Repository Item for additional details). However, these data need to be supplemented with additional VGPs in order to develop a robust paleomagnetic pole that can be confidently used for paleogeographic reconstruction.

We present new paleomagnetic data from 40 lava flows that were sampled along the Two Island River near Schroeder, Minnesota (Fig. 3). The sampled flows range in observed thickness from 1 to $27 \mathrm{~m}$, with a few of the flows likely being thicker, but with exact thickness unconstrained due to partial exposure (Fig. 3). Pipe vesicles are commonly found at the base of flows, while the interiors of the flows have ophitic to subophitic textures (Fig. 3). Well-exposed flow tops typically display pahoehoe textures (Fig. 3). Vesiculated and hypervesiculated sections of the flows are amygdaloidal, and oxidation of the flows is apparent in the red hematite staining of rocks and in the red color of drill water during core sampling. Thin clastic dikes were observed within seven flows in the Two Island River section. Forty-four flows in total were identified within $444 \mathrm{~m}$ of measured section along the Two Island River, with 40 flows sampled as paleomagnetic sites. Along the nearby Cross River, $3 \mathrm{~km}$ to the northeast, John Green observed 44 flows through $460 \mathrm{~m}$ of section (Green, 1992). The exact same number of flows is likely coincidental, given that thin flows would be expected to pinch out over that length scale. However, the thicker flows should correlate, and a similar total number of flows is expected, as is observed.

Thermal demagnetization data from the Schroeder-Lutsen basalt specimens reveal simple, single-component magnetizations (Fig. 4). Magnetizations unblock both through temperatures consistent with a (titano) magnetite-held remanence (up to $580{ }^{\circ} \mathrm{C}$ ) and through higher temperatures $\left(>580{ }^{\circ} \mathrm{C}\right)$ consistent with a hematite-held remanence. In many specimens, significant remanence unblocks between $580{ }^{\circ} \mathrm{C}$ and $625^{\circ} \mathrm{C}$ (Fig. 4), suggesting that remanence is held by maghemite and is therefore a chemically modified thermal remanence. Within single samples and sites for which unblocking temperatures are suggestive of remanence held by both mineralogies, the remanence directions are indistinguishable. Within single samples, the average difference between fits made to the portion of the demagnetization spectra between $\sim 400-580{ }^{\circ} \mathrm{C}$ and $590-680{ }^{\circ} \mathrm{C}$ is $\sim 2.9^{\circ}$ (see Data Repository Item for additional details). Site directions are reported in Table 2.

Combining these directions with the 10 Schroeder-Lutsen basalt sites of Tauxe and Kodama (2009), we calculated a paleomagnetic pole for the Schroeder-Lutsen basalts at $187.8^{\circ} \mathrm{E}, 27.1^{\circ} \mathrm{N}, A_{95}=3.0, N=50$, which is distinct from the pole of the North Shore Volcanic Group. Similar to paleomagnetic data from the Lake Shore Traps, the VGPs from the SchroederLutsen basalts are irregularly clustered, comprising two distinct populations (one more northerly and one more southerly; Fig. 6). Consequently, the overall VGP population is not consistent with a Fisherian distribution as determined through the Fisher Q-Q test (see Data Repository Item). Paleomagnetic data from both VGP populations encompass the full range of rock magnetic behavior exhibited by the Schroeder-Lutsen basalts, and the two populations occur at repeated stratigraphic levels such that the less commonly seen southerly population does not appear to be the result of transient excursional behavior. Additionally, the structural orientation of flows remained consistent throughout the measured section, such that faulting or differential deformation is not a likely explanation for this VGP offset. The VGP clustering observed in both the Schroeder-Lutsen basalts and the Lake Shore Traps could be the result of geomagnetic phenomena leading to secular variation patterns that caused such clustering. Regardless, the $A_{95}$ uncertainty ellipse for the mean pole developed for the Schroeder-Lutsen basalts overlaps both that from the Portage Lake Volcanics and the Lake Shore Traps. Overall, its position is consistent with the Schroeder-Lutsen basalts being temporally in between the poles from the Portage Lake Volcanics and the Lake Shore Traps.

The Schroeder-Lutsen basalts have been interpreted to correlate with the base of the Portage Lake Volcanics (Miller et al., 1995), which erupted during the main stage of Midcontinent Rift volcanism. Our new age constraint for the Schroeder-Lutsen basalt—suggesting emplacement after $1091.61 \pm 0.14 \mathrm{Ma}$ - is more consistent with their assignment to the late stage of rift magmatism. However, both the geochronology and paleomagnetic constraints could be compatible with the basalts correlating with the uppermost flows of the Portage Lake Volcanics above the Greenstone Flow and predating the Lake Shore Traps. Regardless of this specific correlation, these data indicate that olivine tholeiitic basalts continued to be a component of rift magmatism as late into rift history as $1091 \mathrm{Ma}$ or younger.

\section{Michipicoten Island Formation}

\section{Geological Setting and Geochronology}

The volcanic rocks of Michipicoten Island in northeastern Lake Superior have long been considered to be some of the youngest in the Midcontinent Rift (Annells, 1974; Palmer and Davis, 1987; Davis and Green, 1997). The extrusive volcanic flows and tuffs dip southward toward the central axis of the rift (Fig. 5). Dips are steeper in the older volcanics of the northern portion of the island $\left(\sim 40^{\circ}\right)$ than in the south $\left(\sim 15-20^{\circ}\right)$. The geology of Michipicoten Island can be divided into three distinct magmatic intervals, the last of which comprises volcanics of the Michipicoten Island Formation and is of primary interest in this study (Fig. 5).

The basal interval consists primarily of subophitic to ophitic olivine tholeiitic basalt flows, termed the Quebec Mine Member by Annells (1974). Annells (1974) argued for the lithostratigraphic correlation of these flows with the upper basalt flows exposed at Mamainse Point (southeast Lake Superior). Regardless of the veracity of this specific correlation, these flows have similarities to other main-stage tholeiitic flows such as the Portage Lake Volcanics (Fig. 1). The paleomagnetism of the Quebec Mine Member was studied by Palmer and Davis (1987), and the resulting seven VGPs share a common mean with the upper basalt flows from Mamainse Point (Swanson-Hysell et al., 2014a), but the significant scatter and low number of sites studied by Palmer and Davis (1987) from the Quebec Mine Member flows do not make this comparison particularly rigorous (see Data Repository Item for details).

Hypabyssal quartz porphyry, granophyre, and intermediate (basaltic andesite in composition) intrusions were emplaced into the Quebec Mine Member basalt flows and interbedded conglomerates. These intrusions dominate the northern half of the bedrock geology of Michipicoten Island (Fig. 5). It has been hypothesized that these intrusions were emplaced in two separate phases, based on the presence of quartz porphyry inclusions within the basaltic andesite and granophyre intrusions (Annells, 1974). Palmer and Davis (1987) reported a U-Pb ID-TIMS zircon date of 1086.5 $+1.3 /-3.0 \mathrm{Ma}$ (concordia intercept date of multigrain fractions) from a sample of a quartz-feldspar porphyry intrusion.

The Michipicoten Island Formation is interpreted to unconformably overlie the intrusions into the Quebec Mine Member and comprises the uppermost units of the island (Fig. 5; Annells, 1974). Much of the stratigraphic thickness of the Michipicoten Island Formation consists of thick, 


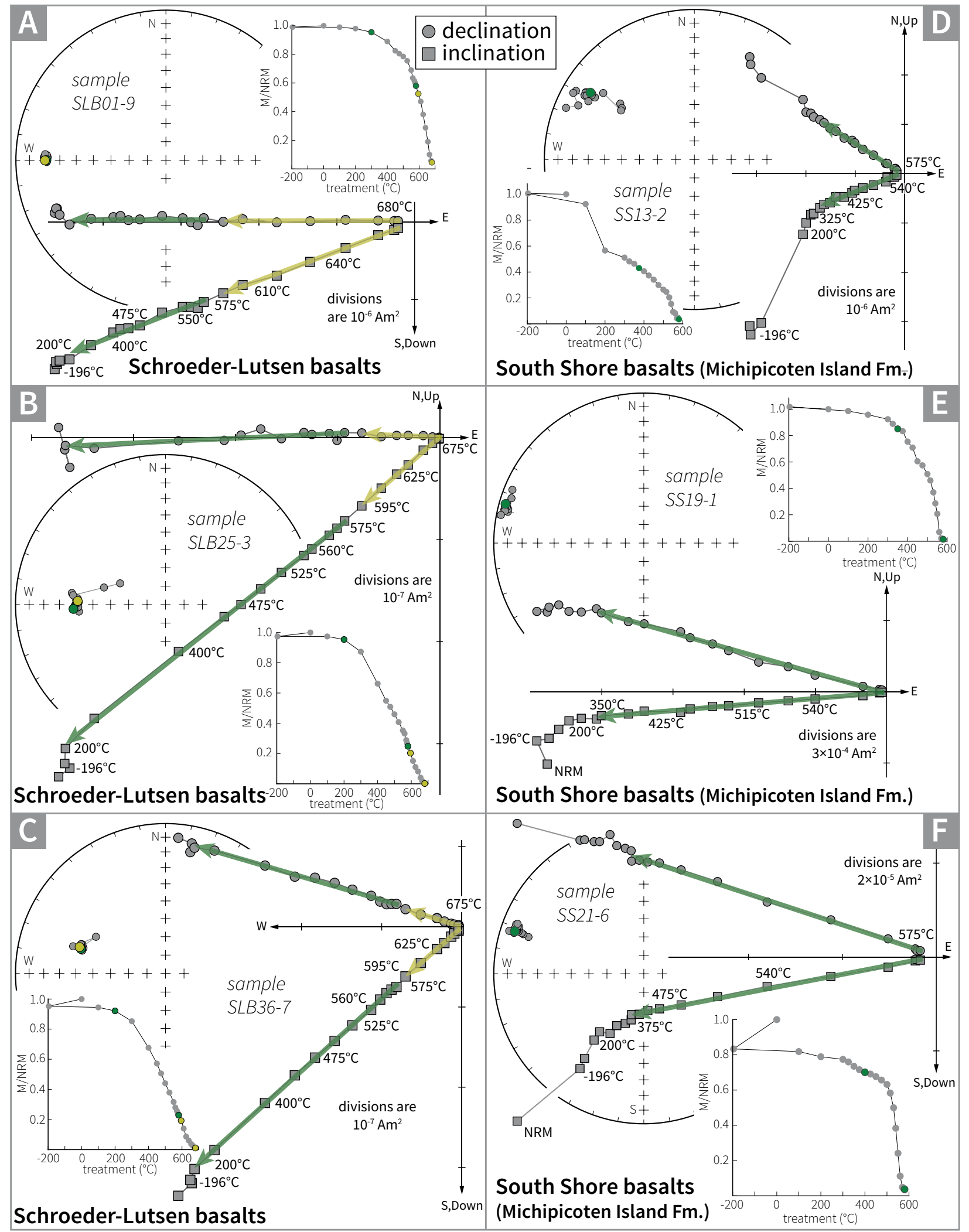

Figure 4. Representative Zijderveld and equal-area plots of paleomagnetic data from specimens of the Schroeder-Lutsen basalts (A, B, C) and the Michipicoten Island South Shore Member basalts (D, E, F). In some samples, a steep northerly component was removed during initial thermal demagnetization (typically up to $200^{\circ} \mathrm{C}$ ), which we interpret as a present-day local field (PLF) overprint. Otherwise, the demagnetization of natural remanent magnetization (NRM) reveals single-component behavior with well-resolved characteristic remanent magnetization directions. 
TABLE 2. PALEOMAGNETIC SITE DATA FROM THE SCHROEDER-LUTSEN BASALTS

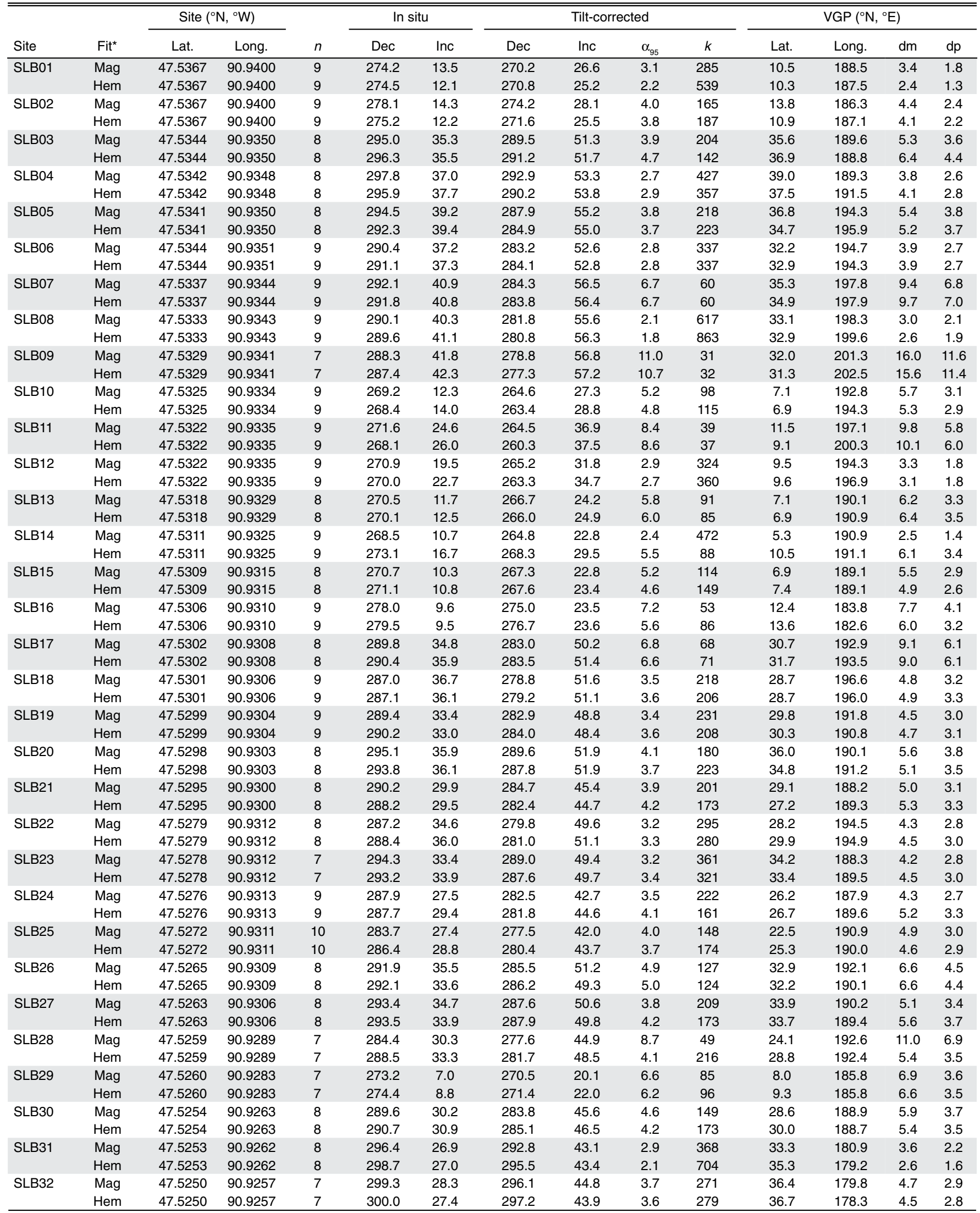

(continued) 
The end of Midcontinent Rift magmatism and the paleogeography of Laurentia | THEMED ISSUE

TABLE 2. PALEOMAGNETIC SITE DATA FROM THE SCHROEDER-LUTSEN BASALTS (continued)

\begin{tabular}{|c|c|c|c|c|c|c|c|c|c|c|c|c|c|c|}
\hline \multirow[b]{2}{*}{ Site } & \multirow[b]{2}{*}{ Fit $^{\star}$} & \multicolumn{2}{|c|}{ Site $\left({ }^{\circ} \mathrm{N},{ }^{\circ} \mathrm{W}\right)$} & \multirow[b]{2}{*}{$n$} & \multicolumn{2}{|c|}{ In situ } & \multicolumn{4}{|c|}{ Tilt-corrected } & \multicolumn{4}{|c|}{$\operatorname{VGP}\left({ }^{\circ} \mathrm{N},{ }^{\circ} \mathrm{E}\right)$} \\
\hline & & Lat. & Long. & & Dec & Inc & Dec & Inc & $\alpha_{95}$ & $k$ & Lat. & Long. & $\mathrm{dm}$ & $\mathrm{dp}$ \\
\hline \multirow[t]{2}{*}{ SLB33 } & Mag & 47.5249 & 90.9256 & 8 & 294.9 & 22.7 & 291.6 & 38.8 & 3.4 & 264 & 30.4 & 179.1 & 4.0 & 2.4 \\
\hline & Hem & 47.5249 & 90.9256 & 8 & 294.2 & 25.6 & 290.4 & 41.6 & 2.8 & 399 & 31.0 & 181.7 & 3.4 & 2.1 \\
\hline \multirow[t]{2}{*}{ SLB34 } & Mag & 47.5249 & 90.9255 & 8 & 292.0 & 27.5 & 287.4 & 43.2 & 3.5 & 248 & 29.8 & 184.8 & 4.3 & 2.7 \\
\hline & Hem & 47.5249 & 90.9255 & 8 & 291.7 & 27.7 & 287.0 & 43.4 & 3.4 & 269 & 29.6 & 185.3 & 4.2 & 2.6 \\
\hline \multirow[t]{2}{*}{ SLB35 } & Mag & 47.5246 & 90.9253 & 9 & 298.2 & 30.4 & 294.5 & 46.8 & 2.6 & 387 & 36.4 & 182.5 & 3.4 & 2.2 \\
\hline & Hem & 47.5246 & 90.9253 & 9 & 297.4 & 28.9 & 293.8 & 45.2 & 2.3 & 484 & 35.1 & 181.7 & 2.9 & 1.8 \\
\hline \multirow[t]{2}{*}{ SLB36 } & Mag & 47.5242 & 90.9242 & 9 & 292.5 & 25.1 & 288.4 & 40.9 & 3.7 & 194 & 29.3 & 182.7 & 4.5 & 2.7 \\
\hline & Hem & 47.5242 & 90.9242 & 9 & 293.2 & 24.2 & 289.4 & 40.1 & 3.8 & 188 & 29.5 & 181.5 & 4.6 & 2.8 \\
\hline \multirow[t]{2}{*}{ SLB37 } & Mag & 47.5241 & 90.9236 & 9 & 297.9 & 30.5 & 294.0 & 46.9 & 2.6 & 390 & 36.1 & 182.9 & 3.4 & 2.2 \\
\hline & Hem & 47.5241 & 90.9236 & 9 & 298.4 & 29.9 & 294.8 & 46.3 & 2.8 & 332 & 36.4 & 181.8 & 3.6 & 2.3 \\
\hline \multirow[t]{2}{*}{ SLB38 } & Mag & 47.5243 & 90.9227 & 8 & 292.0 & 29.9 & 286.9 & 45.6 & 6.7 & 70 & 30.7 & 186.8 & 8.5 & 5.4 \\
\hline & Hem & 47.5243 & 90.9227 & 8 & 294.5 & 30.7 & 289.9 & 46.8 & 7.0 & 63 & 33.3 & 185.7 & 9.0 & 5.8 \\
\hline \multirow[t]{2}{*}{ SLB39 } & Mag & 47.5243 & 90.9226 & 8 & 297.7 & 31.0 & 293.8 & 47.3 & 2.9 & 356 & 36.2 & 183.3 & 3.8 & 2.4 \\
\hline & Hem & 47.5243 & 90.9226 & 8 & 298.8 & 30.6 & 295.2 & 47.1 & 2.7 & 433 & 37.1 & 182.2 & 3.5 & 2.3 \\
\hline \multirow[t]{2}{*}{ SLB40 } & Mag & 47.5243 & 90.9224 & 7 & 297.1 & 36.0 & 292.1 & 52.3 & 5.0 & 147 & 37.9 & 188.8 & 6.9 & 4.7 \\
\hline & Hem & 47.5243 & 90.9224 & 7 & 298.6 & 35.1 & 294.3 & 51.5 & 4.8 & 157 & 38.9 & 186.6 & 6.5 & 4.4 \\
\hline
\end{tabular}

Note: VGP_virtual geomagnetic pole; dp—semi-axis of confidence ellipse along the site-to-pole great-circle path; dm-semi-axis of confidence ellipse perpendicular to site-to-pole great-circle path.

*Mag-magnetite component; Hem-hematite component.

intermediate to felsic flows, which are notable for their excellent preservation, including glassy mesostasis (Palmer et al., 1988). Conglomerate and agglomerate deposits outcrop at the base of the Michipicoten Island Formation. Clasts of both intrusive phases have been identified within these deposits and in the overlying units, such as the West Bay Sand Member tuff, supporting the interpretation that the Michipicoten Island Formation unconformably overlies the intrusive phases and postdates their emplacement (Annells, 1974), although some of the intrusions and flows could be comagmatic. Above these basal deposits, the formation consists of, from bottom to top: (1) glassy glomerophyric andesite flows of the Cuesta Member (total thickness of $\sim 300 \mathrm{~m}$ ), (2) a thin interval of volcaniclastic sandstone overlain by an andesite flow of the Channel Lake Member ( 270 m), (3) green lithic tuff of the West Sandy Bay Member $(\sim 15 \mathrm{~m}),(4)$ thick andesite flows of the Quebec Harbour Member ( 270 $\mathrm{m}$ total), and (5) laminated volcanic tuff and siltstone $(\sim 30 \mathrm{~m})$ overlain by a sequence of relatively thin olivine-free tholeiitic basalt flows of the South Shore Member ( 220 m; Fig. 5; Annells, 1974). Intercalated siltstone and clastic dikes are present in isolated regions of the South Shore Member eruptive sequence. A thin $(5 \mathrm{~cm})$ carbonate bed is found within the easternmost outcrops of the South Shore Member, which, together with the occurrence of quenched flow tops, suggests that some of these eastern flows were erupted into a subaqueous lacustrine environment. Offshore to the south of the main island, the uppermost flow of the Michipicoten Island Formation is a pink-colored rhyolite termed the Davieaux Island Member. This rhyolite constitutes the entire Davieaux Island chain that runs parallel to the south shore of Michipicoten Island (Fig. 5).

There are no reported geochronologic results from the volcanic rocks of the Michipicoten Island Formation. Our U-Pb dating focused on the West Sand Bay Member tuff (sample MI-WSB1) and the Davieaux Island rhyolite (sample MI-DI1). The West Sand Bay tuff sample has a fine-grained, light-green matrix and abundant angular, dark-green-gray, 1-5-mm-sized lithic fragments, some of which are scoriaceous with elongate vesicles. The tuff also contains angular to subangular clasts of red felsite and felsic porphyry that range in size from pebbles to 60 -cm-long boulders. Sample collection sought to avoid these large red lithics, given that they could contribute an older population of zircons. Six out of 10 analyzed zircons from sample MI-WSB1 form a coherent cluster with a weighted mean ${ }^{206} \mathrm{~Pb} /{ }^{238} \mathrm{U}$ date of $1084.35 \pm 0.20 / 0.34 / 1.2 \mathrm{Ma}(\mathrm{MSWD}=0.88$; Table 1 ;
Fig. 2). One older analysis (z7) of possible xenocrystic origin and three resolvably younger analyses (z2, z3, and z4) interpreted to reflect $\mathrm{Pb}$ loss were excluded from the weighted mean date calculation.

The Davieaux Island Member consists of a single thick rhyolite flow, with small feldspar phenocrysts, that is the uppermost exposed flow of the Michipicoten Island Formation (Fig. 5). The rhyolite exhibits flow banding and slab jointing subparallel to this lamination. Excluding one outlier interpreted as xenocrystic, the remaining five zircon analyses from sample MI-DI1 yielded a weighted mean ${ }^{206} \mathrm{~Pb} /{ }^{238} \mathrm{U}$ date of 1083.52 $\pm 0.23 / 0.35 / 1.2 \mathrm{Ma}(\mathrm{MSWD}=0.86)$ for the Davieaux Island rhyolite (Table 1; Fig. 2).

Both of the new $\mathrm{U}-\mathrm{Pb}$ dates from the Michipicoten Island Formation are significantly younger than any date previously reported for Midcontinent Rift volcanic rocks and indicate that the formation is indeed a latestage volcanic complex. The Davieaux Island Member rhyolite may be the youngest exposed lava flow in the entire Midcontinent Rift.

\section{Paleomagnetic Data and Pole}

Reconnaissance paleomagnetic data on Michipicoten Island volcanic rocks by Palmer (1970) revealed consistently normal polarity and were subsequently built upon by Palmer and Davis (1987). In addition to developing data from the lower Quebec Mine Member and the intrusive units, Palmer and Davis (1987) used data from 14 sites to develop a paleomagnetic pole for the Michipicoten Island Formation. However, several of the sites studied by Palmer and Davis (1987) were from the same cooling unit, as determined by our mapping and that of Annells (1974). Given that a mean paleomagnetic pole should not have multiple VGPs from the same cooling unit, we combined redundant sites, leaving eight VGPs available to calculate a mean pole (details of the recalculated pole from Palmer and Davis [1987] are available in the Data Repository Item). In order to have a robust paleomagnetic pole for the Michipicoten Island formation that can be used to constrain paleogeographic reconstructions in conjunction with the new $\mathrm{U}-\mathrm{Pb}$ geochronology for the formation, we sought to develop new paleomagnetic data from additional cooling units of the formation.

As described above, much of the stratigraphic thickness of the Michipicoten Island Formation is composed of thick intermediate to felsic flows. Due to the thickness of these flows, portions of the succession comprise relatively few individual cooling units. Our paleomagnetic sampling focused 


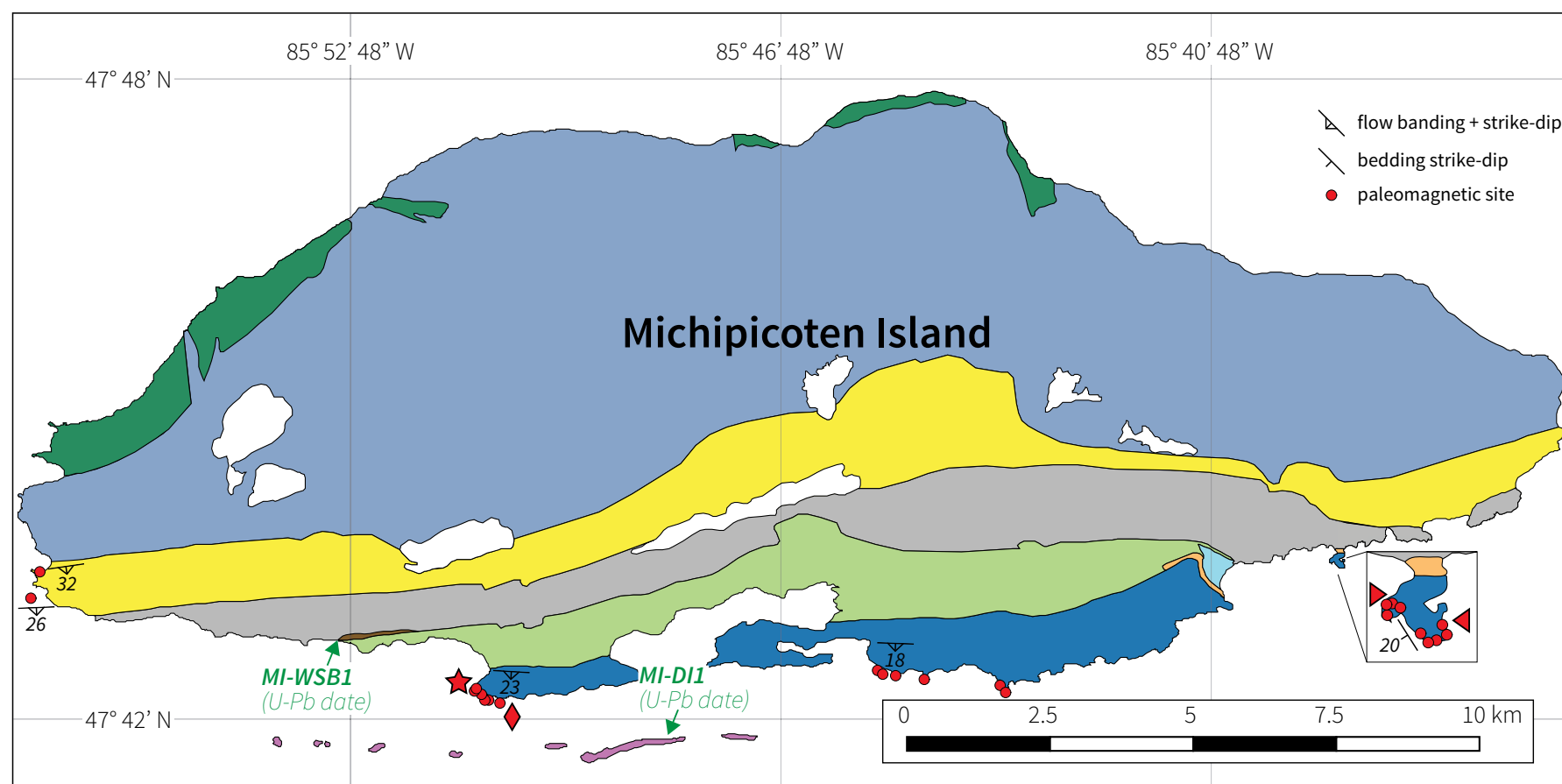

\begin{tabular}{|c|c|c|c|c|}
\hline Davieaux rhyolite & East Sand Bay tuff & Quebec Harbor andesite & $\begin{array}{l}\text { Channel Lake } \\
\text { basaltic andesite }\end{array}$ & Michipicoten intrusions \\
\hline South Shore basalts & $\begin{array}{l}\text { Pleistocene stream } \\
\text { deposits }\end{array}$ & West Sand Bay tuff & Cuesta andesite & Quebec Mine Mem. basalt \\
\hline
\end{tabular}

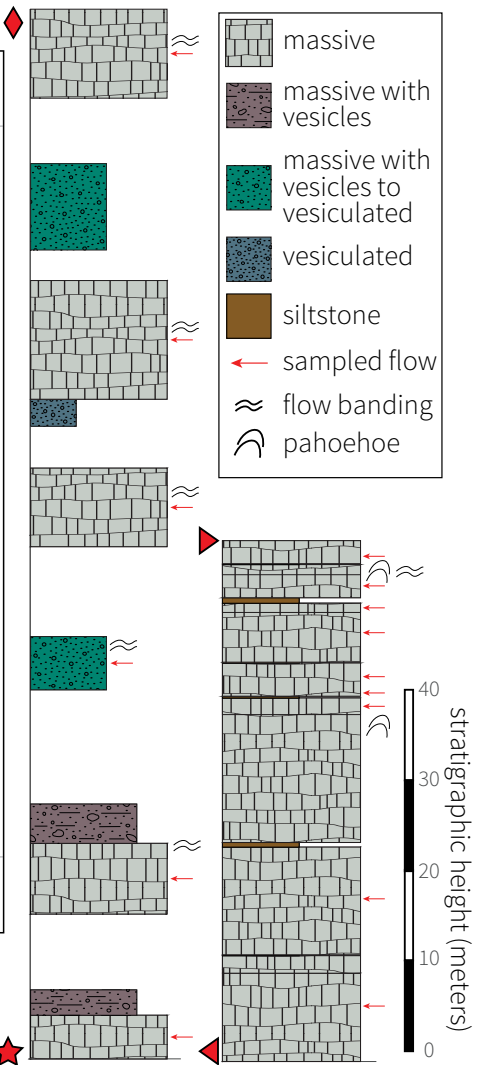

Figure 5. Geologic map of Michipicoten Island adapted from Annells (1974) and new volcanostratigraphic columns through the South Shore Member of the Michipicoten Island Formation. Paleomagnetic sample sites are shown as red dots on the map and red arrows on the stratigraphic columns. The positions of the base and top of the stratigraphic columns are indicated by the red symbols shown to the left of the columns. Mean structural measurements are shown within sampling regions. 
on the South Shore Member tholeiitic basalt flows of the Michipicoten Island Formation because the member consists of numerous and relatively thin flows (from $>30 \mathrm{~m}$ to $\sim 1 \mathrm{~m}$ thick; Fig. 5), resulting in the presence of many more individual cooling units within this member than in the other members combined. The South Shore Member flows are well exposed along the south shore of the island, enabling the measurement of volcanic stratigraphic sections and the collection of samples (Fig. 5). Textural transitions in the basalt sequence (i.e., pipe vesicles present at the flow base, massive basalt in the interior, vesicular to hypervesicular toward the flow top) were used to identify distinct lava flows in the South Shore Member stratigraphy. Twenty-one flows were sampled for paleomagnetic analysis.

Thermal demagnetization data indicate that the characteristic magnetic remanence is held primarily by titanomagnetite and magnetite, with the majority of specimens fully demagnetizing by $580{ }^{\circ} \mathrm{C}$. In three sites, $5 \%-10 \%$ of NRM remained at $580^{\circ} \mathrm{C}$, suggesting the presence of hematite or maghemite. Low-temperature cycling of specimens through the Verwey transition typically resulted in loss of remanence: sometimes up to $\sim 20 \%$ of NRM (Fig. 4). This low-temperature cycling, along with thermal demagnetization up to $\sim 200{ }^{\circ} \mathrm{C}$, commonly removed a steep magnetization component with a northerly declination that we interpret as a present local field viscous overprint (Fig. 4). At higher thermal demagnetization steps (removed by $580{ }^{\circ} \mathrm{C}$ ), a component with W-NW declination and shallow inclination was isolated in all 21 sites and is interpreted as a primary remanence (Fig. 4; Table 3). The new geochronologic data for the West Sand Bay tuff and the Davieaux Island rhyolite presented here tightly bracket the upper units of the Michipicoten Island Formation, which include the Quebec Harbour andesite, the South Shore basalts, and the Davieaux Island rhyolite (Fig. 5). We therefore combined our paleomagnetic data from the South Shore Member with those of Palmer and Davis (1987) from the Quebec Harbour and Davieaux Island Members (recalculating their data to treat these members as single cooling units) in the calculation of a Michipicoten Island Formation paleomagnetic pole at $174.7^{\circ} \mathrm{E}, 17.0^{\circ} \mathrm{N}$,
$A_{95}=4.4^{\circ}, N=23$ (Table 4; Fig. 5). This pole is tightly bracketed in age between $1084.35 \pm 0.20 \mathrm{Ma}$ and $1083.52 \pm 0.23 \mathrm{Ma}$. The distribution of VGPs passes a Fisher Q-Q test and is consistent with the Fisherian model of dispersion about a mean (Fig. 6; Fisher et al., 1987).

\section{DISCUSSION}

\section{Laurentia's Position at the End of Rift Magmatism and Rate of Plate Motion}

The three late-stage rift units outlined here encompass the last stage of Midcontinent Rift magmatism ca. 1092-1083 Ma. These units yield paleomagnetic directions that shallow with progressively younger eruptive ages, consistent with the overall trend of the Keweenawan Track (Table 4; Fig. 7). The new pole for the Michipicoten Island Formation, now the youngest documented pole from rift volcanics on the Keweenawan Track, implies a low latitude for Laurentia and provides new constraints on the rates of plate motion into the late stage of rift magmatism. The rate of implied plate motion between the ca. 1105 Ma Osler Volcanics pole (Davis and Green, 1997) and the new ca. 1084 Ma Michipicoten pole indicates a rate of latitudinal motion of $17.3 \mathrm{~cm} / \mathrm{yr}$, with a $95 \%$ confidence range of $14.5-20.4$ $\mathrm{cm} / \mathrm{yr}$, estimated following the Monte Carlo approach of Swanson-Hysell et al. (2014b) (see Data Repository Item for details of the calculations). The rate between the ca. 1100 Ma Mamainse Point pole (lower normal polarity zone + upper reversed polarity zone; Swanson-Hysell et al., 2009, 2014a) and the Michipicoten pole is estimated by this method to be 14.9 $\mathrm{cm} / \mathrm{yr}$ (95\% confidence range of 11.6-18.3 cm/yr), while the rate of motion between the ca. $1094 \mathrm{Ma}$ (Schoene et al., 2006) North Shore Volcanics pole and the new ca. 1084 Ma Michipicoten pole is estimated to be 18.3 $\mathrm{cm} / \mathrm{yr}$ (95\% confidence range of $13.9-22.8 \mathrm{~cm} / \mathrm{yr}$ ). The similarity between these three separate estimates based on the new Michipicoten data suggest that rapid motion of Laurentia persisted at similar rates throughout

TABLE 3. PALEOMAGNETIC SITE DATA FROM THE MICHIPICOTEN ISLAND FORMATION

\begin{tabular}{|c|c|c|c|c|c|c|c|c|c|c|c|c|c|}
\hline \multirow[b]{2}{*}{ Site } & \multicolumn{2}{|c|}{ Site $\left({ }^{\circ} \mathrm{N},{ }^{\circ} \mathrm{W}\right)$} & \multirow[b]{2}{*}{$\mathrm{n}$} & \multicolumn{2}{|c|}{ In situ } & \multicolumn{4}{|c|}{ Tilt-corrected } & \multicolumn{4}{|c|}{$\operatorname{VGP}\left({ }^{\circ} \mathrm{N},{ }^{\circ} \mathrm{E}\right)$} \\
\hline & Lat. & Lon. & & Dec & Inc & $\mathrm{Dec}$ & Inc & $\alpha_{95}$ & $\mathrm{k}$ & Lat. & Lon. & $\mathrm{dm}$ & $\mathrm{dp}$ \\
\hline $\mathrm{CM} 1$ & 47.7230 & 85.9522 & 8 & 325.6 & -7.5 & 323.8 & 21.0 & 6.6 & 71.0 & 42.3 & 145.7 & 6.9 & 3.7 \\
\hline $\mathrm{CM} 2$ & 47.7190 & 85.9559 & 9 & 303.3 & -9.0 & 303.8 & 6.1 & 1.6 & 1035.0 & 24.4 & 159.7 & 1.6 & 0.8 \\
\hline SS1 & 47.7239 & 85.6483 & 8 & 274.8 & 16.7 & 273.0 & 0.6 & 3.8 & 219.0 & 2.2 & 182.3 & 3.8 & 1.9 \\
\hline SS2 & 47.7236 & 85.6481 & 7 & 291.8 & 10.1 & 290.6 & -1.9 & 6.3 & 92.0 & 13.0 & 168.2 & 6.3 & 3.2 \\
\hline SS3 & 47.7233 & 85.6486 & 10 & 294.4 & 15.7 & 291.5 & 4.3 & 5.5 & 77.0 & 15.9 & 169.5 & 5.5 & 2.8 \\
\hline SS4 & 47.7044 & 85.8514 & 8 & 285.1 & -8.3 & 287.4 & -3.2 & 5.5 & 104.0 & 10.4 & 170.0 & 5.5 & 2.8 \\
\hline SS5 & 47.7036 & 85.8500 & 9 & 300.1 & 17.1 & 291.7 & 25.9 & 7.4 & 49.0 & 24.6 & 177.4 & 7.9 & 4.3 \\
\hline SS6 & 47.7028 & 85.8483 & 8 & 292.7 & -2.9 & 292.4 & 4.7 & 4.6 & 145.0 & 16.7 & 168.8 & 4.6 & 2.3 \\
\hline SS7 & 47.7022 & 85.8453 & 8 & 294.9 & 0.2 & 293.2 & 8.3 & 10.2 & 30.0 & 18.6 & 169.4 & 10.3 & 5.2 \\
\hline SS8 & 47.7047 & 85.8511 & 8 & 277.9 & 11.4 & 273.1 & 12.2 & 4.2 & 173.0 & 6.6 & 186.0 & 4.3 & 2.2 \\
\hline SS9 & 47.7031 & 85.8489 & 8 & 290.5 & 18.0 & 282.0 & 23.2 & 5.5 & 103.0 & 17.0 & 183.6 & 5.9 & 3.1 \\
\hline SS10 & 47.7233 & 85.6489 & 8 & 297.2 & 7.8 & 296.4 & -2.5 & 3.6 & 239.0 & 16.4 & 163.4 & 3.5 & 1.8 \\
\hline SS11 & 47.7238 & 85.6495 & 8 & 298.5 & 9.4 & 297.2 & -0.7 & 3.1 & 312.0 & 17.6 & 163.3 & 3.1 & 1.6 \\
\hline SS12 & 47.7244 & 85.6506 & 9 & 296.4 & 20.3 & 291.9 & 9.3 & 12.4 & 18.0 & 18.1 & 171.0 & 12.3 & 6.2 \\
\hline SS13 & 47.7242 & 85.6508 & 7 & 310.8 & 28.7 & 302.0 & 21.3 & 8.5 & 51.0 & 29.4 & 167.2 & 9.0 & 4.7 \\
\hline SS14 & 47.7244 & 85.6509 & 9 & 301.1 & 17.3 & 297.1 & 7.6 & 5.9 & 77.0 & 20.8 & 166.2 & 5.9 & 3.0 \\
\hline SS15 & 47.7244 & 85.6511 & 9 & 285.8 & 26.7 & 280.7 & 12.7 & 14.7 & 13.0 & 11.9 & 180.8 & 15.0 & 7.6 \\
\hline SS16 & 47.7053 & 85.7292 & 6 & 282.5 & 7.1 & 279.8 & 9.9 & 9.2 & 54.0 & 10.3 & 180.4 & 9.3 & 4.7 \\
\hline SS17 & 47.7042 & 85.7278 & 9 & 294.0 & 21.3 & 286.4 & 26.9 & 4.3 & 147.0 & 21.5 & 182.0 & 4.7 & 2.5 \\
\hline SS18 & 47.7076 & 85.7575 & 9 & 267.6 & 8.9 & 265.1 & 7.2 & 8.8 & 35.0 & -0.6 & 190.3 & 8.9 & 4.5 \\
\hline SS19 & 47.7072 & 85.7567 & 10 & 285.5 & 5.0 & 283.3 & 8.9 & 10.5 & 22.0 & 12.2 & 177.4 & 10.6 & 5.3 \\
\hline SS20 & 47.7061 & 85.7533 & 8 & 308.0 & 18.4 & 301.5 & 28.0 & 2.1 & 688.0 & 32.0 & 170.6 & 2.3 & 1.3 \\
\hline SS21 & 47.7060 & 85.7467 & 9 & 287.2 & 8.2 & 284.1 & 12.5 & 3.5 & 223.0 & 14.1 & 178.0 & 3.5 & 1.8 \\
\hline
\end{tabular}

Note: CM-Cuesta Member andesite; SS—South Shore Member basalts; VGP_virtual geomagnetic pole; dp-semi-axis of confidence ellipse along the site-to-pole great-circle path; $\mathrm{dm}$-semi-axis of confidence ellipse perpendicular to site-to-pole great-circle path. All data are from fits to a component interpreted to be held by (titano)magnetite. 
TABLE 4. SELECTED PALEOMAGNETIC POLES FROM VOLCANICS AND SEDIMENTS OF THE MIDCONTINENT RIFT

\begin{tabular}{|c|c|c|c|c|c|c|}
\hline & PLat $\left({ }^{\circ} \mathrm{N}\right)$ & PLon ( $\left.{ }^{\circ} \mathrm{E}\right)$ & $A_{95}$ & $\mathrm{~N}$ & Paleomagnetic data reference & Age reference and comments \\
\hline Osler Group (upper reversed) & 42.5 & 201.6 & 3.7 & 59 & Swanson-Hysell et al. (2014b) & $1105 \pm 2 \mathrm{Ma}$ (Davis and Green, 1997) \\
\hline $\begin{array}{l}\text { Mamainse Point (lower normal, } \\
\text { upper reversed) }\end{array}$ & 36.1 & 189.7 & 4.9 & 24 & Swanson-Hysell et al. (2014a) & $1100.36 \pm 0.25 \mathrm{Ma}$ (Swanson-Hysell et al., 2014a) \\
\hline $\begin{array}{l}\text { North Shore Volcanic Group } \\
\text { (upper SW sequence) }\end{array}$ & 35.8 & 182.1 & 3.1 & 47 & Tauxe and Kodama (2009) & $\begin{array}{l}\text { Between } 1098.4 \pm 1.9 \mathrm{Ma} \text { and } 1096.6 \pm 1.7 \mathrm{Ma} \\
\text { (Davis and Green, 1997) }\end{array}$ \\
\hline Portage Lake Volcanics & 27.1 & 182.0 & 2.2 & 97 & Books (1972); Hnat et al. (2006) & Ca. $1095 \mathrm{Ma}$ (Davis and Paces, 1990) \\
\hline Schroeder-Lutsen basalts & 27.1 & 187.8 & 3.0 & 50 & This study; Tauxe and Kodama (2009) & $<1091.61 \pm 0.14 \mathrm{Ma}$ (this study) \\
\hline Lake Shore Traps & 23.1 & 186.4 & 4.0 & 31 & Kulakov et al. (2013) & $1085.57 \pm 0.25 \mathrm{Ma}$ (this study) \\
\hline Michipicoten Island Fm. & 17.0 & 174.7 & 4.4 & 23 & This study; Palmer and Davis (1987) & $\begin{array}{l}\text { Between } 1084.35 \pm 0.20 \mathrm{Ma} \text { and } 1083.52 \pm 0.23 \\
\text { Ma (this study) }\end{array}$ \\
\hline Nonesuch Shale & 7.3 & 174.7 & 3.0 & 29 & Symons et al. (2013); Henry et al. (1977) & Ca. $1080 \mathrm{Ma}-$ see text \\
\hline Freda Sandstone & 2.2 & 179.0 & 5.9 & 20 & Henry et al. (1977) & $>1070 \mathrm{Ma}-$ see text \\
\hline Jacobsville Sandstone & -10.0 & 184.0 & 4.2 & 8 & Roy and Robertson (1978) & $<1070 \mathrm{Ma}-$ see text \\
\hline
\end{tabular}
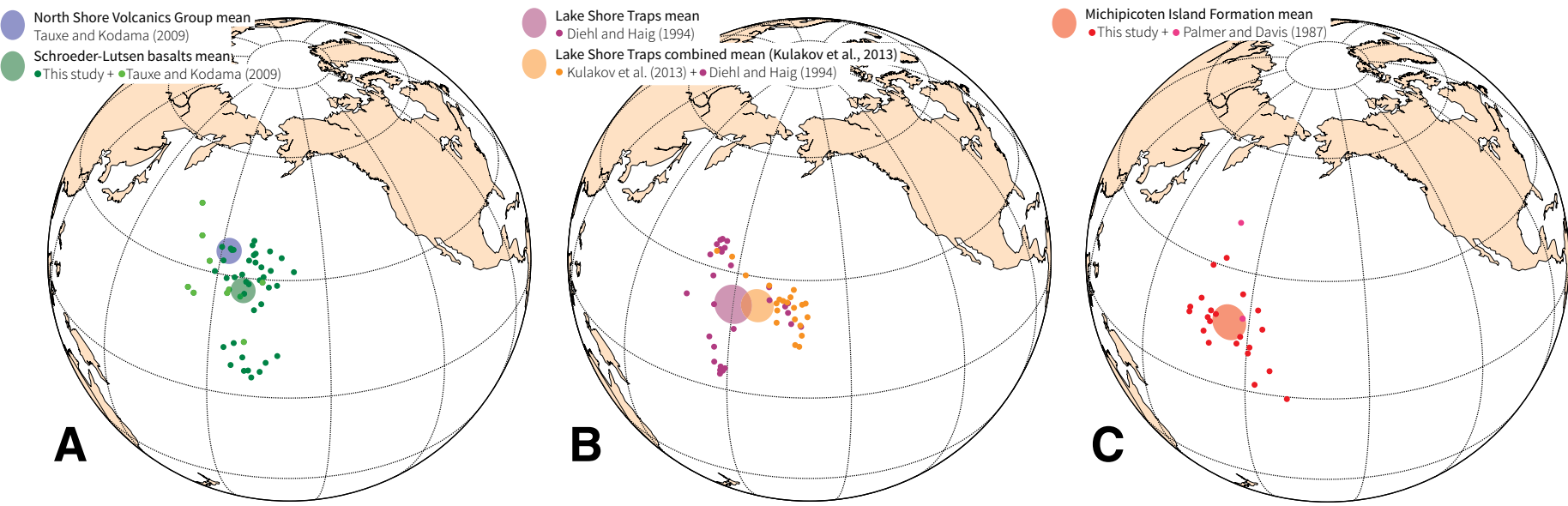

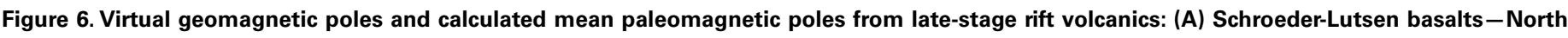

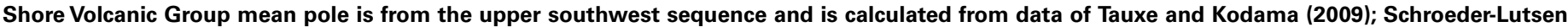

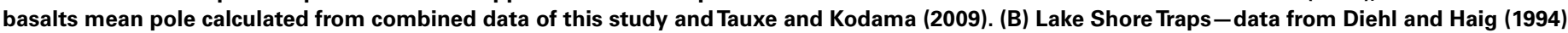

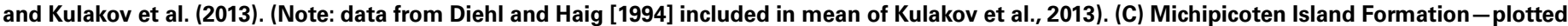

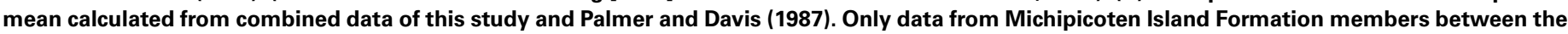
two age constraints (West Sand Bay Member and Davieaux Island Rhyolite Member) are plotted and used in the mean.

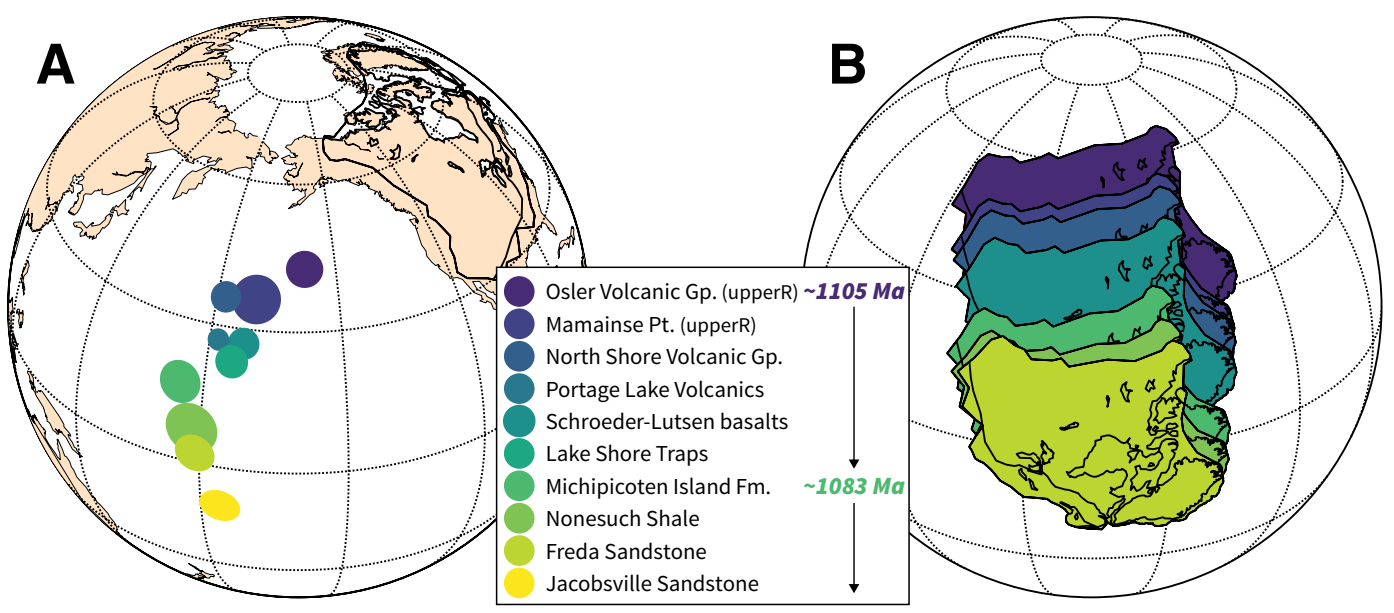

Figure 7. (A) Paleomagnetic poles of the Keweenawan Track listed in Table 4. (B) Paleogeographic reconstructions of Laurentia using the paleomagnetic pole path shown in A. Approximate ages of reconstructions are shown in the figure (age constraints and references are listed in Table 4). 
the entirety of Midcontinent Rift volcanism. These estimates contrast with prior suggestions (e.g., Davis and Green, 1997; Swanson-Hysell et al., 2009) that there was a significant decrease in the rate of this motion as Midcontinent Rift development progressed. Additional high-precision, single-grain CA-ID-TIMS U-Pb geochronology from other successions of the rift integrated with paleomagnetic data in a robust stratigraphic context will enable future improvements to these rate estimates.

\section{Implications for the Age of Keweenawan Sediments}

The cessation of rift volcanism was followed by the accumulation of sediments within the thermally subsiding rift basin (White, 1997; Ojakangas et al., 2001). The Oronto Group, which includes the Copper Harbor Conglomerate, Nonesuch Formation, and Freda Sandstone, is conformable with the Lake Shore Traps and represents the earliest sedimentary deposits to accumulate in the rift basin as volcanism waned and eventually ceased (Fig. 1). These sedimentary rocks are unconformably overlain by the Bayfield Group and the Jacobsville Sandstone, distinguished from the Oronto Group by the dominance of quartz grains and relative lack of lithic detritus (Ojakangas et al., 2001). The depositional ages of these sedimentary successions are poorly constrained, although there are some recent insights from detrital zircon dates from the Jacobsville Sandstone as well as a Re-Os isochron from the Nonesuch Formation (Cumming et al., 2013; Craddock et al., 2013; Malone et al., 2016).

\section{Freda Sandstone and Nonesuch Formations}

Our new paleomagnetic pole for the Michipicoten Island Formation plots closely to the paleomagnetic poles of the Nonesuch Formation and Freda Sandstone (Fig. 7; Henry et al., 1977). Both in its age and position, the Michipicoten Island Formation pole bridges the gap between previous poles of the Keweenawan Track and the poles of these initial rift sediments. The age assignments used in paleomagnetic pole compilations for the Oronto Group (ca. 1050 Ma; e.g., Li et al., 2008) were developed prior to precise geochronological control on the rift. Because they significantly postdate the end of rift magmatism, these ages, assigned to the shallow paleomagnetic directions of the Oronto Group, have led to the interpretation of a slowdown of Laurentia's motion as the craton straddled the equator at the end of Midcontinent Rift magmatism. However, there is strong evidence for deposition of the Oronto Group earlier and closer to the end of rift magmatism at ca. $1083 \mathrm{Ma}$. The Nonesuch Shale interfingers and is conformable with the underlying Copper Harbor Conglomerate (Elmore et al., 1989), within which the Lake Shore Traps erupted at ca. $1086 \mathrm{Ma}$. The Freda Sandstone, which overlaps and is conformable with the Nonesuch Shale, is composed of $30 \%$ lithic fragments derived equally from metamorphic rock and felsic volcanic rocks with minor mafic lithic fragments (Ojakangas and Dickas, 2002). The geologic relationships and compositional nature of the Freda Sandstone are consistent with deposition in a thermally subsiding rift basin with input from eroding Midcontinent Rift volcanics. The presence of the Bear Lake Felsite (Cannon and Nicholson, 2001) within the Freda Sandstone on the Keweenaw Peninsula suggests that deposition of the Freda Sandstone did not significantly postdate deposition of the Nonesuch Shale and occurred while rift magmatism was still active. Additionally, the paleomagnetic data of Henry et al. (1977) for the Freda Sandstone come from the lower $670 \mathrm{~m}$ of the formation, which has a total estimated thickness of $>3600 \mathrm{~m}$ (Ojakangas et al., 2001). The pole should therefore date to the oldest part of Freda Sandstone deposition. Last, the proximity of late-rift volcanic paleomagnetic poles to those of Oronto Group sedimentary formations is consistent with deposition of the Oronto Group shortly after the end of Midcontinent Rift magmatism, although such proximity alone does not require this temporal relationship. It is noteworthy that the Oronto Group poles are relatively insensitive to inclination flattening within sediments, as paleomagnetic data from the Nonesuch Shale and Freda Sandstone exhibit both shallow positive and negative inclinations (Henry et al., 1977), such that inclination correction would have a negligible effect on their mean directions (i.e., both upper and lower hemisphere directions would be steepened during unflattening, leaving a mean direction similar to the original). We propose that age assignments for these Oronto Group poles should be ca. 1083 to ca. $1070 \mathrm{Ma}$, similar to the age assignments for these poles proposed by Swanson-Hysell et al. (2012). This age assignment for the Nonesuch pole is consistent with Re-Os geochronologic data, which were interpreted to provide a $1078 \pm 24$ Ma depositional age for the Nonesuch Shale (Cumming et al., 2013).

A potential complication of this age assignment is the local mineralization and oxidation of the Nonesuch Shale. Based on these characteristics, it has been argued that the magnetization of the Nonesuch Shale is secondary and much younger than its deposition (Symons et al., 2013). Symons et al. (2013) assigned an age of $1063 \pm 8$ Ma to this magnetization by extrapolating the Keweenawan Track using the rate of plate motion implied by the offset of paleomagnetic poles from the Portage Lake Volcanics and the Lake Shore Traps. However, our new estimate for Laurentia's rate of motion during the late stage of rift magmatism suggests that its date is much closer to $1080 \mathrm{Ma}$ (see Data Repository Item). It therefore seems likely that if Nonesuch magnetization is secondary, it (and associated hydrothermal activity) did not significantly postdate deposition. This older age assignment for the Nonesuch Shale magnetization is consistent with it having been acquired before or during burial by the Freda Sandstone, the age of which is likely not much younger than ca. $1080 \mathrm{Ma}$, due to the presence of the Bear Lake Felsite.

\section{Jacobsville Formation}

The Jacobsville Sandstone and correlative Bayfield Group are interpreted to unconformably overlie the Oronto Group (Ojakangas et al., 2001). Paleomagnetic data for the Jacobsville have led to a paleomagnetic pole position that appears to be a continuation of the Keweenawan Track from the Oronto Group poles (Roy and Robertson, 1978; Fig. 7; Table 4). As a result, its age has been interpolated to be latest Mesoproterozoic (e.g., $1020 \mathrm{Ma}$ in $\mathrm{Li}$ et al., 2008) such that it was deposited prior to the ca. $1000 \mathrm{Ma}$ Grenville loop poles. However, this age assignment has recently been questioned on the basis of laser-ablation-inductively coupled plasma-mass spectrometry (LA-ICP-MS) U-Pb detrital zircon dates from Jacobsville Sandstone samples. Malone et al. (2016) interpreted a maximum depositional age of $959 \pm 19$ Ma based on the weighted mean of the four youngest grains from 2050 LA-ICP-MS zircon dates. A similar age was proposed on the basis of the youngest LA-ICP-MS U-Pb dates in the study of Craddock et al. (2013). This young maximum interpreted age is intriguing because it suggests the unconformity above the Freda Sandstone spans at least 100 m.y. and was followed by continued sedimentation in the region long after rift activity. Nevertheless, the paleomagnetic pole of the Jacobsville Sandstone (Roy and Robertson, 1978) appears to extend the Keweenawan Track from the Oronto Group poles in a manner that is consistent with deposition of the Jacobsville Sandstone in the late Mesoproterozoic. Given the conflict with this inferred age, the large uncertainty of individual LA-ICP-MS dates, and the possibility of outlier dates in such a large data set, it would be beneficial for the youngest Jacobsville zircons to be analyzed using CA-ID-TIMS to obtain more precise constraints.

Malone et al. (2016) further proposed that the age of the Jacobsville Sandstone is most likely between 780 and $755 \mathrm{Ma}$, or younger still, based on matching the absolute value of the paleolatitude of the Jacobsville 
Sandstone paleomagnetic data with that implied for other Laurentian poles. However, considering only the absolute value of the paleolatitude neglects the constraints on polarity that are available within the APWP Laurentia's APWP requires that Laurentia crossed the equator in the late Mesoproterozoic and thereby intersected the paleolatitude corresponding to the Jacobsville paleomagnetic pole at that time, as can be seen if the paleolatitude analysis is carried out in both hemispheres (Fig. 8). Furthermore, there is an 200 m.y. gap in the paleomagnetic record for Laurentia between ca. 970 and $770 \mathrm{Ma}$, during which Laurentia could have been located at low latitudes. One avenue to adding more constraints to this paleolatitudinal record would be to include paleomagnetic poles from cratons taken to be conjoined with Laurentia at the time. Baltica is widely considered to have been in a paleogeographic position that reconstructs
Baltica's Caledonian margin to the southeastern Greenland margin of Laurentia (Pisarevsky et al., 2003; Li et al., 2008; Evans, 2009). Here, we elect to use the reconstruction of Evans (2009; Euler rotation of Baltica to Laurentia of $81.5^{\circ} \mathrm{N}, 250.0^{\circ} \mathrm{E}, 50^{\circ}$ clockwise). Such a reconstruction connects the Sveconorwegian orogen to the Grenville orogen in southeast Greenland (Gower and Krogh, 2002). The alignment of paleomagnetic pole swathes in this configuration (the Grenville loop for Laurentia and the Sveconorwegian loop for Baltica) has also been argued to support such a connection (e.g., Piper, 1980). However, as discussed in Evans et al. (2015) and evident in Figure 8, more recent data indicate that the poles from Baltica are temporally distinct from those of Laurentia. As a result, the combined APWP has multiple oscillations that reconstruct the conjoined continents to have crossed through low latitudes four times between

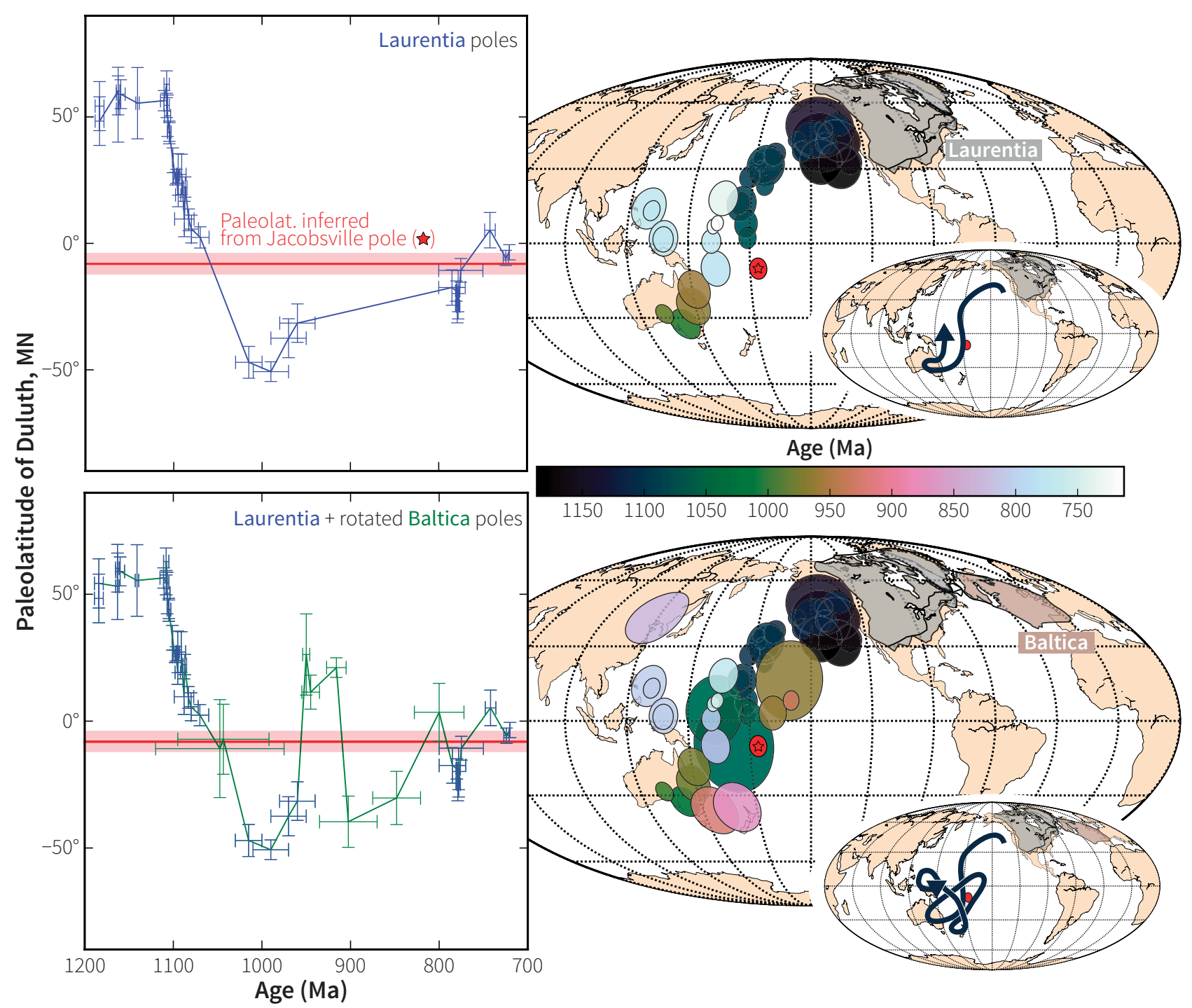

Figure 8. Paleolatitude of Duluth, Minnesota (reference location representative of the Lake Superior region of Laurentia) throughout the interval 1200-700 Ma inferred from paleomagnetic poles (apparent polar wander path [APWP]) compiled by the 2014 Nordic Supercontinent Workshop, Haraldvangen, Norway. APWP poles are shown on large globes to the right of the paleolatitude plots, and their simplified path is outlined on smaller inset globes. The top panel includes only paleomagnetic poles of Laurentia (Piper, 1977, 1992; Denyszyn et al., 2009; Maloof et al., 2006; Weil et al., 2003, 2006; Park et al., 1989; Warnock et al., 2000; Henry et al., 1977; Kulakov et al., 2013; Donadini et al., 2011; Kean et al., 1997; Hnat et al., 2006; Tauxe and Kodama, 2009; Swanson-Hysell et al., 2014a, 2014b; Ernst and Buchan, 1993). The bottom panel adds paleomagnetic poles of Baltica (Stearn and Piper, 1984; Mertanen et al., 1996; Elming et al., 2014; Walderhaug et al., 1999; Pavlov and Gallet, 2010), with Baltica rotated to Laurentia in the reconstruction of Evans (2009). 
1080 and $780 \mathrm{Ma}$ (Fig. 8). This analysis, whether Baltica is included or not, indicates that the paleomagnetic database does not require an age for the Jacobsville pole that is $780 \mathrm{Ma}$ or younger, although such an age is possible.

Ideally, paleomagnetic constraints on the age of the Jacobsville Sandstone would involve direct correlation with the poles of the Laurentian APWP rather than paleolatitude comparison alone. Although the Jacobsville pole most readily appears to be a continuation of the Keweenawan Track, it also falls on the early Cambrian segment of Laurentia's APWP (as compiled by Torsvik et al., 2012) and completely overlaps the $A_{95}$ error of the ca. 532 Ma paleomagnetic pole (McCausland et al., 2007). This similarity suggests that a Cambrian age is a possible alternative to Mesoproterozoic deposition of the Jacobsville Sandstone. Given that reverse faults juxtapose rift volcanics with the Jacobsville Sandstone (e.g., the Keweenaw fault), a Cambrian age would imply significant structural reworking of the rift sometime within or after the Cambrian-most likely during one or more phases of Appalachian mountain building (Hatcher, 2010). However, the dramatic structural offset due to Midcontinent Rift fault inversion (up to $5 \mathrm{~km}$; Cannon et al., 1989) does not continue into overlying Paleozoic sediments: current geologic mapping indicates minimal $(<100 \mathrm{~m})$ to no offset of Middle Cambrian to Ordovician strata along the reactivated Douglas, Pine, Lake Owen, and Hinckley faults that bound the St. Croix horst southwest of Lake Superior (Boerboom, 2001; Setterholm, 2010; Cannon et al., 1993). These geological data appear inconsistent with significant Paleozoic deformation in the region and reinforce the importance of developing more precise age constraints on the Jacobsville Sandstone.

\section{Implications for the Timeline of Rift Development and the End of Rifting}

In resolving the evolution of the Midcontinent Rift, the longevity of active extensional structures remains a key question. Given the extent of hypothesized lithospheric thinning (White, 1997), there would have been appreciable thermal subsidence following the end of active extension that could have provided accommodation space for additional volcanics and sediments within the rift basin. A recent structural reanalysis of the 1986 GLIMPCE seismic data posited that rift-related faulting within the Midcontinent Rift ended prior to the eruption of the Portage Lake Volcanics at ca. $1096 \mathrm{Ma}$, with all subsequent accommodation space arising from thermal subsidence (Stein et al., 2015). Our new U-Pb dates of 1084.35 $\pm 0.20 \mathrm{Ma}$ and $1083.52 \pm 0.23 \mathrm{Ma}$ for Michipicoten Island Formation volcanics indicate that this proposed timing of the end of active structures would predate the end of rift-related volcanism in the Lake Superior region by more than 12 million years.

Additional evidence of ongoing differential structural activity comes from the angular unconformity atop the Beaver Bay Complex. Rift flank uplift is commonly associated with fault-driven subsidence, particularly that occurring in relatively narrow rift zones (Sachau and Koehn, 2010). As a result, there is a much higher potential for unconformities to be associated with intervals of active rifting rather than the broad thermal subsidence that follows. The angular unconformity at the contact between the North Shore Volcanic Group and the Schroeder-Lutsen basalts likely represents a zone of localized rift flank uplift during active extension. The new Silver Bay intrusion age of 1091.61 \pm 0.14 Ma from below the unconformity suggests that differential structural development associated with active extension was ongoing ca. $1091 \mathrm{Ma}$.

The cause of the Midcontinent Rift's failure to develop into an ocean basin has been an enduring question. Rifting has been attributed to: (1) far-field stresses with different proposed tectonic drivers (e.g., Gordon and Hempton, 1986; Stein et al., 2014) that initiated extension into which plume-derived melts erupted (Green, 1983; Stein et al., 2015); and (2) an upwelling mantle plume that drove crustal thinning and rifting (Burke and Dewey, 1973; Cannon and Hinze, 1992). The new paleomagnetic pole from the Michipicoten Island Formation implies that, from the start to end of rift magmatism, Laurentia had traveled more than $45^{\circ}$ of latitude, $20^{\circ}$ of which were covered from the main stage of rift volcanism at ca. $1095 \mathrm{Ma}$ to the end of rift volcanism at ca. $1083 \mathrm{Ma}$. A plume source has been invoked for early to main-stage magmatism, given the prodigious volume (Cannon, 1992) and $\varepsilon_{\mathrm{Nd}(t)}$ values of $\sim 0$ (Nicholson and Shirey, 1990; Nicholson et al., 1997). While Laurentia's APWP could have a significant component of true polar wander that caused a plume to have moved in conjunction with the lithosphere, the latitudinal change could also represent migration away from an anomalous heat source in the mantle that resulted in cessation of rifting and associated magmatic activity. The cumulative plate motion could represent a critical distance at which lateral conduits for plume-derived melts ("upside-down drainage"; Sleep, 1997; Ebinger and Sleep, 1998) were no longer tenable.

\section{CONCLUSIONS}

New high-precision U-Pb dates from the Michipicoten Island Formation are the youngest yet obtained from the Midcontinent Rift and indicate that magmatism in the Lake Superior region continued until ca. $1084 \mathrm{Ma}$. A new pole from the Michipicoten Island Formation is tightly constrained in time and connects poles obtained from Midcontinent Rift volcanics (including those from the Schroeder-Lutsen basalts and Lake Shore Traps) with those from overlying sedimentary rocks. This addition to the Keweenawan Track supports the interpretation, consistent with other geological constraints, that the Nonesuch Formation and Freda Sandstone and their associated poles date to ca. 1080-1070 Ma. The new Michipicoten Island Formation pole also indicates that rapid rates of plate motion continued through to the end of rift volcanism.

\section{ACKNOWLEDGMENTS}

This research was supported by National Science Foundation (NSF) grant EAR-1045635 to Swanson-Hysell and NSF grant EAR-1419822 to Bowring and Ramezani. Minnesota Power is acknowledged and thanked for permission to conduct field work along the Two Island River. Ontario Parks is acknowledged and thanked for permits to conduct field work within Michipicoten Island Provincial Park. Constructive reviews from Henry Halls and Don Davis improved this manuscript. John Green, Terry Boerboom, and Jim Miller provided helpful insight into the geology of the North Shore Volcanic Group, the Schroeder-Lutsen basalts and the Beaver Bay Complex. Discussions with David Evans informed our perspective on the implication of a combined Laurentia and Baltica APWP. Conversations with Bill Cannon motivated additional consideration of geological relationships along the Douglas and other reactivated faults. Kevin Gaastra is thanked for his assistance with paleomagnetic measurements. Code developed as part of the collaborative open source PmagPy project (www.github .com/PmagPy) was used throughout the work.

\section{REFERENCES CITED}

Annells, R., 1974, Keweenawan Volcanic Rocks of Michipicoten Island, Lake Superior, Ontario: An Eruptive Centre of Proterozoic Age: Geological Survey of Canada Bulletin 218, 156 p., doi:10.4095/103500.

Blackburn, T.J., Olsen, P.E., Bowring, S.A., McLean, N.M., Kent, D.V., Puffer, J., McHone, G., Rasbury, E.T., and Et-Touhami, M., 2013, Zircon U-Pb geochronology links the end-Triassic extinction with the Central Atlantic magmatic province: Science, v. 340, p. 941-945, doi: 10.1126/science.1234204.

Boerboom, T.J., 2001, C-13: Pine County Geologic Atlas, Minnesota: Part A. Geology: Minnesota Geological Survey, scale: 1:100,000.

Boerboom, T.J., and Green, J.C., 2006, Bedrock Geology of the Schroeder Quadrangle, Cook County, Minnesota: Minnesota Geological Survey Miscellaneous Map Series M-170, scale $1: 24,000$.

Books, K., 1972, Paleomagnetism of Some Lake Superior Keweenawan Rocks: U.S. Geological Survey Professional Paper P-0760, $42 \mathrm{p}$.

Bowring, J.F., McLean, N.M., and Bowring, S.A., 2011, Engineering cyber infrastructure for $\mathrm{U}-\mathrm{Pb}$ geochronology:Tripoli and U-Pb_Redux: Geochemistry Geophysics Geosystems v. 12, Q0AA19, doi:10.1029/2010GC003479.

Burgess, S.D., Bowring, S.A., Fleming,T.H., and Elliot, D.H., 2015, High-precision geochronology links the Ferrar large igneous province with Early Jurassic ocean anoxia and biotic crisis: Earth and Planetary Science Letters, v. 415, p. 90-99, doi:10.1016/j.epsl.2015.01.037. 
Burke, K., and Dewey, J.F., 1973, Plume-generated triple junctions: Key indicators in applying plate tectonics to old rocks:The Journal of Geology, v. 81, p. 406-433, doi:10.1086/627882.

Cannon, W.F., 1992, The Midcontinent Rift in the Lake Superior region with emphasis on its geodynamic evolution:Tectonophysics, v. 213, p. 41-48, doi:10.1016/0040-1951(92)90250-A

Cannon, W.F., 1994, Closing of the Midcontinent Rift-A far-field effect of Grenvillian compression: Geology, v. 22, p. 155-158, doi:10.1130/0091-7613(1994)022<0155:COTMRA>2.3.CO;2

Cannon, W.F., and Hinze, W.J., 1992, Speculations on the origin of the North American Midcontinent Rift:Tectonophysics, v. 213, p. 49-55, doi:10.1016/0040-1951(92)90251-Z.

Cannon, W.F., and Nicholson, S.W., 2001, Geologic Map of the Keweenaw Peninsula and Adjacent Area, Michigan: U.S. Geological Survey Geologic Investigations Map I-2696, 7 p.

Cannon, W.F., Green, A.G., Hutchinson, D.R., Lee, M., Milkereit, B., Behrendt, J.C., Halls, H.C., Green, J.C., Dickas, A.B., Morey, G.B., Sutcliffe, R., and Spencer, C., 1989, The North American Midcontinent Rift beneath Lake Superior from GLIMPCE seismic reflection profiling Tectonics, v. 8, p. 305-332, doi:10.1029/TC008i002p00305.

Cannon, W.F., Peterman, Z.E., and Sims, P.K., 1993, Crustal-scale thrusting and origin of the Montreal River monocline-A 35-km-thick cross section of the Midcontinent Rift in northern Michigan and Wisconsin:Tectonics, v. 12, p. 728-744, doi:10.1029/93TC00204.

Condon, D.J., Schoene, B., McLean, N.M., Bowring, S.A., and Parrish, R.R., 2015, Metrology and traceability of $\mathrm{U}-\mathrm{Pb}$ isotope dilution geochronology (EARTHTIME tracer calibration part i): Geochimica et Cosmochimica Acta, v. 164, p. 464-480, doi:10.1016/j.gca.2015.05.026

Craddock, J.P., Konstantinou, A., Vervoort, J.D., Wirth, K.R., Davidson, C., Finley-Blasi, L., Juda N.A., and Walker, E., 2013, Detrital zircon provenance of the Mesoproterozoic Midcon tinent Rift, Lake Superior region, U.S.A.: The Journal of Geology, v. 121, p. 57-73, doi: 10.1086/668635

Cumming, V.M., Poulton, S.W., Rooney, A.D., and Selby, D., 2013, Anoxia in the terrestrial environment during the late Mesoproterozoic: Geology, v. 41, p. 583-586, doi:10.1130 /G34299.1, http://geology.gsapubs.org/content/41/5/583.

Davis, D., and Green, J., 1997, Geochronology of the North American Midcontinent Rift in western Lake Superior and implications for its geodynamic evolution: Canadian Journa of Earth Sciences, v. 34, p. 476-488, doi:10.1139/e17-039.

Davis, D., and Paces, J., 1990,Time resolution of geologic events on the Keweenaw Peninsula and applications for development of the Midcontinent Rift system: Earth and Planetary Science Letters, v. 97, p. 54-64, doi:10.1016/0012-821X(90)90098-I.

Davis, D., and Sutcliffe, R., 1985, U-Pb ages from the Nipigon plate and northern Lake Superior: Geological Society of America Bulletin, v. 96, p. 1572-1579, doi:10.1130/0016-7606 (1985)96<1572:UAFTNP>2.0.CO;2.

Denyszyn, S.W., Halls, H.C., Davis, D.W., and Evans, D.A.D., 2009, Paleomagnetism and U-Pb geochronology of Franklin dykes in High Arctic Canada and Greenland: A revised age and paleomagnetic pole constraining block rotations in the Nares Strait region: Canadian Journal of Earth Sciences, v. 46, p. 689-705, doi:10.1139/E09-042.

Diehl, J., and Haig, T., 1994, A paleomagnetic study of the lava flows within the Copper Harbour Conglomerate, Michigan: New results and implications: Canadian Journal of Earth Sciences, v. 31, p. 369-380, doi:10.1139/e94-034.

Donadini, F., Pesonen, L.J., Korhonen, K., Deutsch, A., and Harlan, S.S., 2011, Paleomagnetism and paleointensity of the $1.1 \mathrm{Ga}$ old diabase sheets from central Arizona: Geophysica, v. 47, p. 3-30.

Ebinger, C.J., and Sleep, N.H., 1998, Cenozoic magmatism throughout East Africa resulting from impact of a single plume: Nature, v. 395, p. 788-791, doi:10.1038/27417.

Elming, S.-Å., Pisarevsky, S.A., Layer, P., and Bylund, G., 2014, A palaeomagnetic and ${ }^{40} \mathrm{Ar} /{ }^{39} \mathrm{Ar}$ study of mafic dykes in southern Sweden: A new Early Neoproterozoic key-pole for the Baltic Shield and implications for Sveconorwegian and Grenville loops: Precambrian Research, v. 244, p. 192-206, doi:10.1016/j.precamres.2013.12.007.

Elmore, R., Milavec, G.J., Imbus, S.W., and Engel, M.H., 1989, The Precambrian Nonesuch Formation of the North American Mid-continent Rift, sedimentology and organic geochemical aspects of lacustrine deposition: Precambrian Research, v. 43, p. 191-213, doi: 10.1016/0301-9268(89)90056-9.

Ernst, R., and Buchan, K., 1993, Paleomagnetism of the Abitibi dike swarm, southern Superior Province, and implications for the Logan loop: Canadian Journal of Earth Sciences, v. 30 p. 1886-1897, doi:10.1139/e93-167.

Evans, D., 2009, The palaeomagnetically viable, long-lived and all-inclusive Rodinia supercontinent reconstruction, in Murphy, J., Keppie, J., and Hynes, A., eds., Ancient Orogens and Modern Analogues: Geological Society of London Special Publication 327, p. 371-404 doi:10.1144/sp327.16

Evans, D.A.D.,Trindade, R.I.F, Catelani, E.L., D'Agrella-Filho, M.S., Heaman, L.M., Oliveira, E.P Söderlund, U., Ernst, R.E., Smirnov, A.V., and Salminen, J.M., 2015, Return to Rodinia? Moderate to high palaeolatitude of the São Francisco/Congo craton at $920 \mathrm{Ma}$, in Li, Z.X. Evans, D.A.D., Murphy, J.B., eds., Supercontinent CyclesThrough Earth History: Geological Society of London Special Publication 424, doi:10.1144/SP424.1.

Feinberg, J., Solheid, P., Swanson-Hysell, N., Jackson, M., and Bowles, J., 2015, Full vector low-temperature magnetic measurements of geologic materials: Geochemistry, Geophysics, Geosystems, v. 16, p. 301-314, doi:10.1002/2014GC005591.

Fisher, N.I., Lewis, T., and Embleton, B.J.J., 1987, Statistical Analysis of Spherical Data: Cambridge, UK, Cambridge University Press, 344 p., doi:10.1017/CBO9780511623059.

Fisher, R., 1953, Dispersion on a sphere: Proceedings of the Royal Society of London, ser. A, Mathematical and Physical Sciences, v. 217, p. 295-305, doi:10.1098/rspa.1953.0064.

Gordon, M., and Hempton, M., 1986, Collision-induced rifting: The Grenville orogeny and the Keweenawan rift of North America:Tectonophysics, v. 127, p. 1-25, doi:10.1016/0040 1951(86)90076-4.

Gower, C., and Krogh, T., 2002, A U-Pb geochronological review of the Proterozoic history of the eastern Grenville Province: Canadian Journal of Earth Sciences, v. 39, p. 795-829, doi:10.1139/e01-090.
Green, J., 1983, Geologic and geochemical evidence for the nature and development of the Middle Proterozoic (Keweenawan) Midcontinent Rift of North America:Tectonophysics, v. 94, p. 413-437, doi:10.1016/0040-1951(83)90027-6.

Green, J.C., 1992, Geologic Map of the North Shore of Lake Superior, Lake and Cook Counties Minnesota: Part 1. Little Marais to Tofte: Minnesota Geological Survey Map M-071 scale $1: 24,000$

Green, J.C., Boerboom, T.J., Schmidt, S.T., and Fitz,T.J., 2011, The North Shore Volcanic Group: Mesoproterozoic plateau volcanic rocks of the Midcontinent Rift system in northeastern Minnesota, in Miller, J.D., Hudak, G.J., Wittkop, C., and McLaughlin, P.I., eds., Archean to Anthropocene: Field Guides to the Geology of the Mid-Continent of North America: Geological Society of America Field Guide 24, p. 121-146, doi:10.1130/2011.0024(07).

Halls, H., and Pesonen, L., 1982, Paleomagnetism of Keweenawan rocks, in Wold, R.J., and Hinze, W.J., eds., Geology and Tectonics of the Lake Superior Basin: Geological Society of America Memoir 156, p. 173-202, doi:10.1130/MEM156-p173.

Hatcher, R.D., 2010, The Appalachian Orogen: A brief summary, in Tollo, R.P., Bartholomew, M.J., Hibbard, J.P., and Karabinos, P.M., eds., From Rodinia to Pangea:The Lithotectonic Record of the Appalachian Region: Boulder, Colorado, Geological Society of America Memoir 206, p. 1-19, doi:10.1130/2010.1206(01).

Henry, S., Mauk, F., and der Voo, R.V., 1977, Paleomagnetism of the upper Keweenawan sediments: Nonesuch Shale and Freda Sandstone: Canadian Journal of Earth Science, v. 14 p. 1128-1138, doi:10.1139/e77-103.

Hnat, J.S., van der Pluijm, B.A., and Van der Voo, R., 2006, Primary curvature in the MidContinent Rift: Paleomagnetism of the Portage Lake Volcanics (northern Michigan, USA): Tectonophysics, v. 425, p. 71-82, doi:10.1016/j.tecto.2006.07.006.

Hutchinson, D. White, R. Cannon, W., and Schulz, K., 1990, Keweenaw hot spot: Geophysical evidence for a $1.1 \mathrm{Ga}$ mantle plume beneath the Midcontinent Rift system: Journal of Geophysical Research-Solid Earth (1978-2012), v. 95, p. 10,869-10,884, doi:10.1029 /jb095ib07p10869.

Jaffey, A.H., Flynn, K.F., Glendenin, L.E., Bentley, W.C., and Essling, A.M., 1971, Precision measurement of half-lives and specific activities of ${ }^{235} \mathrm{U}$ and ${ }^{238} \mathrm{U}$ : Physical Review C: Nuclear Physics, v. 4, no. 5, p. 1889-1906, doi:10.1103/PhysRevC.4.1889.

Jirsa, M.A., Boerboom, T., Chandler, V., Mossler, J., Runkel, A., and Setterholm, D., 2011, Geologic Map of Minnesota-Bedrock Geology: Minnesota Geological Survey Map S-21 scale 1:500,000

Kean, W., Williams, I., and Feeney, J., 1997, Magnetism of the Keweenawan age Chengwatana lava flows, northwest Wisconsin: Geophysical Research Letters, v. 24, p. 1523-1526, doi: 10.1029/97GL00993.

Kirschvink, J., 1980, The least-squares line and plane and the analysis of paleomagnetic data: Geophysical Journal of the Royal Astronomical Society, v. 62, p. 699-718, doi:10.1111/j 1365-246X.1980.tb02601.x.

Kirschvink, J.L., Kopp, R.E., Raub, T.D., Baumgartner, C.T., and Holt, J.W., 2008, Rapid, precise, and high-sensitivity acquisition of paleomagnetic and rock-magnetic data: Development of a low-noise automatic sample changing system for superconducting rock magnetometers: Geochemistry Geophysics Geosystems, v. 9, Q05Y01, doi:10.1029/2007GC001856.

Krogh, T.E., 1982, Improved accuracy of U-Pb zircon ages by the creation of more concordant systems using an air abrasion technique: Geochimica et Cosmochimica Acta, v. 46, no. 4 p. 637-649, doi:10.1016/0016-7037(82)90165-X.

Kulakov, E.V., Smirnov, A.V., and Diehl, J.F., 2013, Paleomagnetism of 1.09 Ga Lake Shore Traps (Keweenaw Peninsula, Michigan): New results and implications: Canadian Journal of Earth Sciences, v. 50, p. 1085-1096, doi:10.1139/cjes-2013-0003.

Lane, A., 1911, The Keweenaw Series of Michigan: No. 6, Pt. 1: Michigan Geological and Biological Survey Publication 6, $281 \mathrm{p}$

Li, Z.X., et al., 2008, Assembly, configuration, and break-up history of Rodinia: A synthesis: Precambrian Research, v. 160, p. 179-210, doi:10.1016/j.precamres.2007.04.021.

Malone, D.H., Stein, C.A., Craddock, J.P., Kley, J., Stein, S., and Malone, J.E., 2016, Maximum depositional age of the Neoproterozoic Jacobsville Sandstone, Michigan: Implications for the evolution of the Midcontinent Rift: Geosphere, v. 12, no. 4, p. 1271-1282, doi: 10.1130/GES01302.1.

Maloof, A., Halverson, G., Kirschvink, J., Schrag, D., Weiss, B., and Hoffman, P., 2006, Combined paleomagnetic, isotopic and stratigraphic evidence for true polar wander from the Neoproterozoic Akademikerbreen Group, Svalbard, Norway: Geological Society of America Bulletin, v. 118, p. 1099-1124, doi:10.1130/B25892.1

Mattinson, J.M., 2005, Zircon U/Pb chemical abrasion (CA-TIMS) method: Combined annealing and multi-step partial dissolution analysis for improved precision and accuracy of zircon ages: Chemical Geology, v. 220, p. 47-66, doi:10.1016/j.chemgeo.2005.03.011.

Mattinson, J.M., 2010, Analysis of the relative decay constants of ${ }^{235} \mathrm{U}$ and ${ }^{238} \mathrm{U}$ by multi-step CA-TIMS measurements of closed-system natural zircon samples: Chemical Geology, v. 275 , no. $3-4$, p. $186-198$

McCabe, C., and Van der Voo, R., 1983, Paleomagnetic results from the upper Keweenawan Chequamegon Sandstone: Implications for red bed diagenesis and Late Precambrian apparent polar wander of North America: Canadian Journal of Earth Sciences, v. 20, p. 105-112, doi:10.1139/e83-010.

McCausland, P.J.A., Van der Voo, R., and Hall, C.M., 2007, Circum-lapetus paleogeography of the Precambrian-Cambrian transition with a new paleomagnetic constraint from Laurentia: Precambrian Research, v. 156, p. 125-152, doi:10.1016/j.precamres.2007.03.004

McLean, N.M., Bowring, J.F., and Bowring, S.A., 2011, An algorithm for U-Pb isotope dilution data reduction and uncertainty propagation: Geochemistry Geophysics Geosystems, v. 12 , Q0AA18, doi:10.1029/2010GC003478.

McLean, N.M., Condon, D.J., Schoene, B., and Bowring, S.A., 2015, Evaluating uncertainties in the calibration of isotopic reference materials and multi-element isotopic tracers (EARTHTIME Tracer Calibration Part II): Geochimica et Cosmochimica Acta, v. 164, p. 481-501, doi:10.1016/j.gca.2015.02.040. 
Mertanen, S., Pesonen, L., and Huhma, H., 1996, Paleomagnetism and Sm-Nd ages of the Neoproterozoic diabase dykes in Laanila and Kautokeino, northern Fennoscandia, in Brewer, T., ed., Precambrian Crustal Evolution in the North Atlantic Region: Geological Society of London Special Publication 112, p. 331-358, doi:10.1144/gsl.sp.1996.112.01.18.

Miller, J.D., and Chandler, V.W., 1997, Geology, petrology, and tectonic significance of the Beaver Bay Complex, northeastern Minnesota, in Ojakangas, R.W.O., Dickas, A.B., and Green, J.C., eds., Middle Proterozoic to Cambrian Rifting, Central North America: Geological Society of America Special Paper 312, p. 73-96, doi:10.1130/0-8137-2312-4.73.

Miller, J.D., and Green, J., 2002, Geology of the Beaver Bay Complex and related hypabyssal intrusions, in Geology and Mineral Potential of the Duluth Complex and Related Rocks of Northeastern Minnesota: Minnesota Geological Survey Report of Investigations 58, p. 144-163.

Miller, J.D., and Nicholson, S.W., 2013, Geology and mineral deposits of the $1.1 \mathrm{Ga}$ Midcontinent Rift in the Lake Superior region-An overview, in Miller, J., ed., Field Guide to the Cu-Ni-PGE Deposits of the Lake Superior Region: Precambrian Research Center Guidebook 13-1, p. 1-50

Miller, J.D., and Vervoort, J.D., 1996, The latent magmatic stage of the Midcontinent Rift: A period of magmatic underplating and melting of the lower crust: Institute on Lake Superior Geology Proceedings, v. 42, p. 33-35.

Miller, J.D., Green, J.C., and Boerboom, T.J., 1989, Geologic Map of the Illgen City Quadrangle, Lake County, Minnesota: Minnesota Geological Survey Map M-66, scale 1:24,000.

Miller, J.D., Chandler, V.W., Green, J.C., and Witthuhn, K., 1995, The Finland tectono-magmatic discontinuity-A growth fault marking the western margin of the Portage Lake Volcanic Basin of the Midcontinent Rift system, in Ojakangas, R.W.O., Dickas, A.B., and Green, J.C., eds., BasementTectonics 10: Dordrecht, Netherlands, Springer, p. 35-40, doi:10.1007 1978-94-017-0831-9 8.

Miller, J.D., Green, J., and Jerde, A., 2006, Bedrock Geology of the Little Marais Quadrangle Cook County, Minnesota: Minnesota Geological Survey Miscellaneous Map Series M 172.

Nicholson, S.W., and Shirey, S.B., 1990, Midcontinent Rift volcanism in the Lake Superior region: $\mathrm{Sr}, \mathrm{Nd}$, and $\mathrm{Pb}$ isotopic evidence for a mantle plume origin: Journal of Geophysical Research, v. 95, p. 10,851-10,868, doi:10.1029/JB095iB07p10851.

Nicholson, S.W., Shirey, S., Schultz, K., and Green, J., 1997, Rift-wide correlation of $1.1 \mathrm{Ga}$ Midcontinent Rift system basalts: Implications for multiple mantle sources during rift development: Canadian Journal of Earth Sciences, v. 34, p. 504-520, doi:10.1139/e17-041.

Nicholson, S.W., Dicken, C.L., Foose, M.P., and Mueller, J.A.L., 2004, Integrated Geologic Map Databases of the United States: The Upper Midwest States: Minnesota, Wiscon sin, Michigan, Illinois and Indiana: U.S. Geological Survey Open-File Report 2004-1355.

Ojakangas, R.W., and Dickas, A.B., 2002, The 1.1-Ga Midcontinent Rift system, central North America: Sedimentology of two deep boreholes, Lake Superior region: Sedimentary Geology, v. 147, p. 13-36, doi:10.1016/S0037-0738(01)00185-3.

Ojakangas, R.W., Morey, G.B., and Green, J.C., 2001, The Mesoproterozoic Midcontinent Rift system, Lake Superior region, USA: Sedimentary Geology, v. 141-142, p. 421-442, doi: 10.1016/S0037-0738(01)00085-9.

Ontario Geological Survey, 2011, Bedrock Geology of Ontario: Ontario Geological Survey Miscellaneous Release Data 126, Revision 1, scale 1:250,000.

Paces, J., and Miller, J., 1993, Precise U-Pb ages of Duluth Complex and related mafic intrusions, northeastern Minnesota: Geochronological insights to physical, petrogenetic, paleomagnetic and tectonomagmatic processes associated with the $1.1 \mathrm{Ga}$ Midcontinent Rift system: Journal of Geophysical Research, v. 98, p. 13,997-14,013, doi:10.1029/93JB01159.

Palmer, H., 1970, Paleomagnetism and correlation of some Middle Keweenawan rocks, Lake Superior: Canadian Journal of Earth Sciences, v. 7, p. 1410-1436, doi:10.1139/e70-136.

Palmer, H., and Davis, D., 1987, Paleomagnetism and U-Pb geochronology of volcanic rocks from Michipicoten Island, Lake Superior, Canada: Precise calibration of the Keweenawan polar wander track: Precambrian Research, v. 37, p. 157-171, doi:10.1016/0301-9268(87)90077-5.

Palmer, H.C., Tazaki, K., Fyfe, W.S., and Zhou, Z., 1988, Precambrian glass: Geology, v. 16 p. 221-224, doi:10.1130/0091-7613(1988)016<0221:PG>2.3.CO;2.

Park, J., Norris, D., and LaRochelle, A., 1989, Paleomagnetism and the origin of the Mackenzie Arc of northwestern Canada: Canadian Journal of Earth Sciences, v. 26, p. 2194-2203, doi:10.1139/e89-186.

Pavlov, V., and Gallet, Y., 2010, Variations in geomagnetic reversal frequency during the Earth's middle age: Geochemistry Geophysics Geosystems, v. 11, 001Z10, doi:10.1029 /2009GC002583.

Piper, J.D.A., 1977, Palaeomagnetism of the giant dykes of Tugtutoq and Narssaq Gabbro, Gardar Igneous Province, South Greenland: Bulletin of the Geological Society of Denmark, v. 26, p. 85-94.

Piper, J.D.A., 1980, Analogous Upper Proterozoic apparent polar wander loops: Nature, v. 283 p. 845-847, doi:10.1038/283845a0.

Piper, J.D.A., 1992, The palaeomagnetism of major (Middle Proterozoic) igneous complexes, South Greenland and the Gardar apparent polar wander track: Precambrian Research, v. 54, p. 153-172, doi:10.1016/0301-9268(92)90068-Y.

Pisarevsky, S., Wingate,T., Powell, C.M., Johnson, S., and Evans, D., 2003, Models of Rodinia assembly and fragmentation, in Yoshida, M., Windley, B., and Dasgupta, S., eds., Pro terozoic East Gondwana: Supercontinent Assembly and Breakup: Geological Society of London Special Publication 206, p. 35-55, doi:10.1144/gsl.sp.2003.206.01.04.

Ramezani, J., Hoke, G.D., Fastovsky, D.E., Bowring, S.A., Therrien, F., Dworkin, S.I., Atchley, S.C., and Nordt, L.C., 2011, High-precision U-Pb zircon geochronology of the LateTriassic Chinle Formation, Petrified Forest National Park (Arizona, USA):Temporal constraints on the early evolution of dinosaurs: Geological Society of America Bulletin, v. 123, no. 11-12, p. 2142-2159, doi:10.1130/B30433.1.

Renne, P.R., Sprain, C.J., Richards, M.A., Self, S., Vanderkluysen, L., and Pande, K., 2015, State shift in Deccan volcanism at the Cretaceous-Paleogene boundary, possibly induced by impact: Science, v. 350, p. 76-78, doi:10.1126/science.aac7549.
Roy, J., and Robertson, W., 1978, Paleomagnetism of the Jacobsville Formation and the apparent polar wander path for the interval $\sim 1100$ to $~ 670$ m.y. for North America: Journal of Geophysical Research, v. 83, p. 1289-1304, doi:10.1029/JB083iB03p01289.

Sachau, T., and Koehn, D., 2010, Faulting of the lithosphere during extension and related riftflank uplift: A numerical study: International Journal of Earth Sciences, v. 99, p. 1619-1632, doi:10.1007/s00531-010-0513-6.

Schoene, B., Crowley, J.L., Condon, D.J., Schmitz, M.D., and Bowring, S.A., 2006, Reassessing the uranium decay constants for geochronology using ID-TIMS U-Pb data: Geochimica et Cosmochimica Acta, v. 70, p. 426-445, doi:10.1016/j.gca.2005.09.007.

Setterholm, D.R., 2010, Geologic Atlas of Chisago County, Minnesota: Part A: Minnesota Geological Survey Map C-22, scale: 1:100,000 and 1:200,000.

Sleep, N.H., 1997, Lateral flow and ponding of starting plume material: Journal of Geophysical Research-Solid Earth, v. 102, p. 10,001-10,012, doi:10.1029/97JB00551.

Stearn, J., and Piper, J., 1984, Palaeomagnetism of the Sveconorwegian mobile belt of the Fennoscandian Shield: Precambrian Research, v. 23, p. 201-246, doi:10.1016/0301-9268 (84)90045-7.

Stein, C.A., Kley, J., Stein, S., Hindle, D., and Keller, G.R., 2015, North America's Midcontinent Rift:When rift met LIP: Geosphere, v. 11, no. 5, p. 1607-1616, doi:10.1130/GES01183.1.

Stein, C.A., Stein, S., Merino, M., Keller, R.G., Flesch, L.M., and Jurdy, D.M., 2014, Was the Midcontinent Rift part of a successful seafloor-spreading episode?: Geophysical Research Letters, v. 41, p. 1465-1470, doi:10.1002/2013GL059176.

Swanson-Hysell, N.L., Maloof, A.C., Weiss, B.P., and Evans, D.A.D., 2009, No asymmetry in geomagnetic reversals recorded by 1.1-billion-year-old Keweenawan basalts: Nature Geoscience, v. 2, p. 713-717, doi:10.1038/ngeo622.

Swanson-Hysell, N.L., Maloof, A.C., Kirschvink, J.L., Evans, D.A.D., Halverson, G.P., and Hurtgen, M.T., 2012, Constraints on Neoproterozoic paleogeography and Paleozoic orogenesis from paleomagnetic records of the Bitter Springs Formation, Amadeus Basin, cen tral Australia: American Journal of Science, v. 312, p. 817-884, doi:10.2475/08.2012.01.

Swanson-Hysell, N.L., Burgess, S.D., Maloof, A.C., and Bowring, S.A., 2014a, Magmatic activity and plate motion during the latent stage of Midcontinent Rift development: Geology, v. 42 , p. $475-478$, doi:10.1130/G35271.1.

Swanson-Hysell, N.L., Vaughan, A.A., Mustain, M.R., and Asp, K.E., 2014b, Confirmation of progressive plate motion during the Midcontinent Rift's early magmatic stage from the Osler Volcanic Group, Ontario, Canada: Geochemistry Geophysics Geosystems, v. 15 p. 2039-2047, doi:10.1002/2013GC005180.

Symons, D.T.A., Kawasaki, K., and Diehl, J.F., 2013, Age and genesis of the White Pine stratiform copper mineralization, northern Michigan, USA, from paleomagnetism: Geofluids v. 13 , p. $112-126$, doi:10.1111/gfl.12024.

Tauxe, L., and Kodama, K., 2009, Paleosecular variation models for ancient times: Clues from Keweenawan lava flows: Physics of the Earth and Planetary Interiors, v. 177, p. 31-45 doi:10.1016/j.pepi.2009.07.006

Tauxe, L., Shaar, R., Jonestrask, L., Swanson-Hysell, N., Minnett, R., Koppers, A., Constable, C., Jarboe, N., Gaastra, K., and Fairchild, L., 2016, PmagPy: Software package for paleomagnetic data analysis and a bridge to the Magnetics Information Consortium (MaglC) Database: Geochemistry Geophysics Geosystems, v. 17, p. 2450-2463, doi:10 1002/2016GC006307.

Torsvik, T.H., Van der Voo, R., Preeden, U., Mac Niocaill, C., Steinberger, B., Doubrovine, P.V., van Hinsbergen, D.J.J., Domeier, M., Gaina, C. Tohver, E., Meert, J.G., McCausland, P.J.A. and Cocks, L.R.M., 2012, Phanerozoic polar wander, palaeogeography and dynamics: Earth-Science Reviews, v. 114, p. 325-368, doi:10.1016/j.earscirev.2012.06.007.

Vervoort, J.,Wirth, K., Kennedy, B., Sandland, T., and Harpp, K., 2007, The magmatic evolution of the Midcontinent Rift: New geochronologic and geochemical evidence from felsic mag matism: Precambrian Research, v. 157, p. 235-268, doi:10.1016/j.precamres.2007.02.019.

Verwey, E.J.W., 1939, Electronic conduction of magnetite $\left(\mathrm{Fe}_{3} \mathrm{O}_{4}\right)$ and its transition point at low temperatures: Nature, v. 144, p. 327-328, doi:10.1038/144327b0.

Walderhaug, H., Torsvik, T., Eide, E., Sundvoll, E., and Bingen, B., 1999, Geochronology and palaeomagnetism of the Hunnedalen dykes, SW Norway: Implications for the Sveconorwegian apparent polar wander loop: Earth and Planetary Science Letters, v. 169, p. 71-83, doi:10.1016/S0012-821X(99)00066-7.

Warnock, A., Kodama, K., and Zeitler, P., 2000, Using thermochronometry and low-temperature demagnetization to accurately date Precambrian paleomagnetic poles: Journal of Geophysical Research, v. 105, p. 19,435-19,453, doi:10.1029/2000JB900114.

Weil, A., Geissman, J., Heizler, M., and Van der Voo, R., 2003, Paleomagnetism of Middle Proterozoic mafic intrusions and Upper Proterozoic (Nankoweap) red beds from the Lower Grand Canyon Supergroup, Arizona:Tectonophysics, v. 375, p. 199-220, doi:10.1016 /S0040-1951(03)00339-1.

Weil, A.B., Geissman, J.W., and Ashby, J.M., 2006, A new paleomagnetic pole for the Neoproterozoic Uinta Mountain Supergroup, central Rocky Mountain states, USA: Precambrian Research, v. 147, p. 234-259, doi:10.1016/j.precamres.2006.01.017.

White, R.S., 1997, Mantle temperature and lithospheric thinning beneath the Midcontinent Rift system: Evidence from magmatism and subsidence: Canadian Journal of Earth Sciences, v. 34, p. 464-475, doi:10.1139/e17-038.

Zartman, R., Nicholson, S., Cannon, W., and Morey, G., 1997, U-Th-Pb zircon ages of some Keweenawan Supergroup rocks from the south shore of Lake Superior: Canadian Journal of Earth Science, v. 34, p. 549-561, doi: 10.1139/e17-044.

MANUSCRIPT RECEIVED 2 JUNE 2016

REVISED MANUSCRIPT RECEIVED 4 OCTOBER 2016

MANUSCRIPT ACCEPTED 17 NOVEMBER 2016

Printed in the USA 